\title{
Estimate of the Distribution of Solids Within Mixed Hanford Double-Shell Tank AZ-101: Implications for AY-102
}

\author{
BE Wells \\ JJ Ressler
}

April 2009

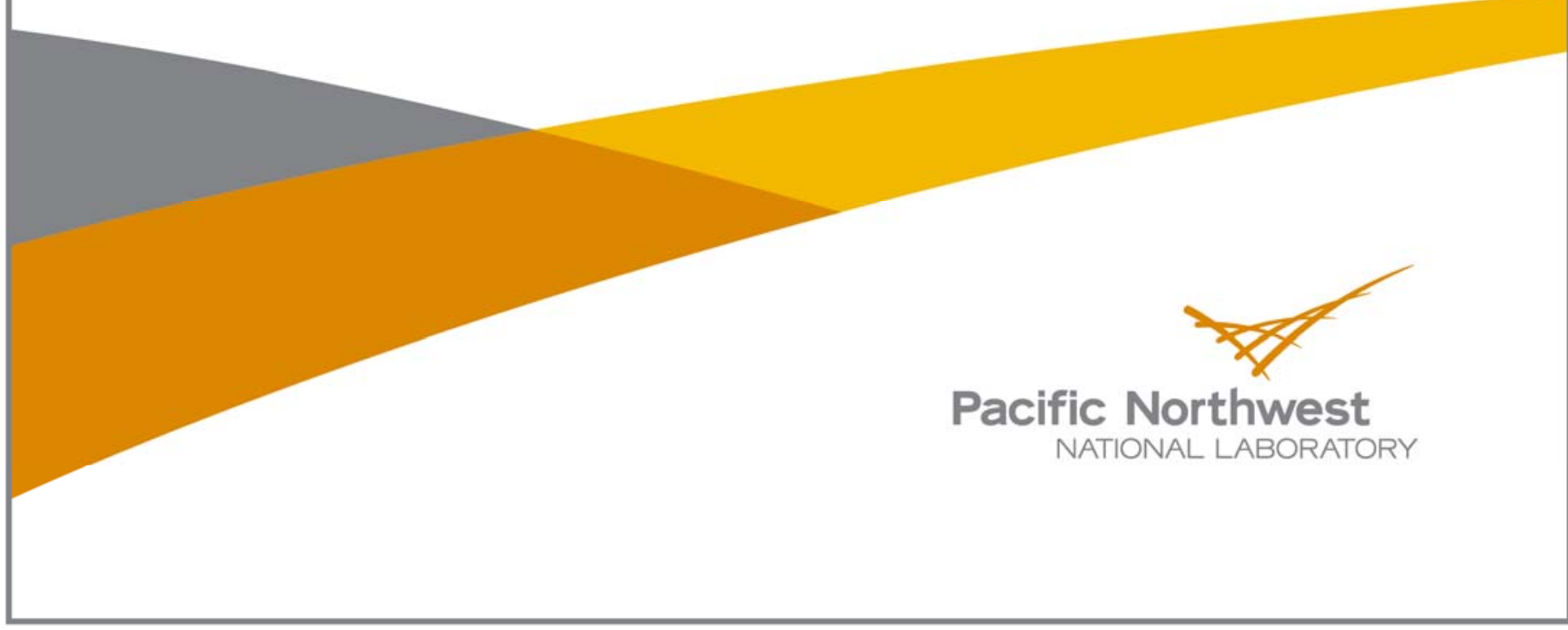




\title{
DISCLAIMER
}

This report was prepared as an account of work sponsored by an agency of the United States Government. Neither the United States Government nor any agency thereof, nor Battelle Memorial Institute, nor any of their employees, makes any warranty, express or implied, or assumes any legal liability or responsibility for the accuracy, completeness, or usefulness of any information, apparatus, product, or process disclosed, or represents that its use would not infringe privately owned rights. Reference herein to any specific commercial product, process, or service by trade name, trademark, manufacturer, or otherwise does not necessarily constitute or imply its endorsement, recommendation, or favoring by the United States Government or any agency thereof, or Battelle Memorial Institute. The views and opinions of authors expressed herein do not necessarily state or reflect those of the United States Government or any agency thereof.

\author{
PACIFIC NORTHWEST NATIONAL LABORATORY \\ operated by \\ BATTELLE \\ for the \\ UNITED STATES DEPARTMENT OF ENERGY \\ under Contract DE-ACO5-76RL01830
}

Printed in the United States of America
Available to DOE and DOE contractors from the
Office of Scientific and Technical Information,
P.O. Box 62, Oak Ridge, TN 37831-0062;
ph: (865) 576-8401
fax: (865) 5765728
email: reports@adonis.osti.gov

\author{
Available to the public from the National Technical Information Service, \\ U.S. Department of Commerce, 5285 Port Royal Rd., Springfield, VA 22161 \\ ph: (800) 553-6847 \\ fax: (703) 605-6900 \\ email: orders@nits.fedworld.gov \\ online ordering: http://www.ntis.gov/ordering.htm
}




\section{Estimate of the Distribution of Solids Within Mixed Hanford Double-Shell Tank AZ-101: Implications for AY-102}

BE Wells

JJ Ressler

April 2009

Prepared for

the U.S. Department of Energy

under Contract DE-AC05-76RL01830

Pacific Northwest National Laboratory

Richland, Washington 



\section{Summary}

This paper describes the current level of understanding of the suspension of solids in Hanford doubleshell waste tanks while being mixed with the baseline configuration of two 300-horsepower mixer pumps. A mixer pump test conducted in Tank AZ-101 during fiscal year 2000 provided the basis for this understanding. Information gaps must be filled to demonstrate the capability of the baseline feed delivery system to effectively mix, sample, and deliver double-shell tank waste to the Hanford Tank Waste Treatment and Immobilization Plant (WTP) for vitrification.

Section 2 describes the distribution of solids in AZ-101 following mixer pump operation. The tank configuration and the best-estimate values of the waste properties during the test are described. It is concluded that the mixing in AZ-101 resulted in suspension of $32 \%$ of the particulate required for homogenous suspension. Section 3 describes the waste properties and tank configuration of Tank AY-102, which is the WTP commissioning feed tank. Section 4 compares the waste properties and tank configuration of the two tanks, and the results of the AZ-101 test are applied to AY-102. The comparison suggests that AY-102 will not be homogenously mixed by the baseline mixing system. The findings are

also applied to Hanford waste in feed staging tanks in general, indicating that the baseline mixing system will face significant challenges in those tanks with regard to homogenous suspension of the Hanford insoluble solids. Finally, there are recommendations for future studies to reduce uncertainties in the homogeneity of mixed tank wastes. 



\section{Acronyms and Abbreviations}

$\begin{array}{ll}\text { ALC } & \text { airlift circulator } \\ \text { DST } & \text { double-shell tank } \\ \text { PSDD } & \text { particle size and density distribution } \\ \text { SSP } & \text { Suspended Solids Profiler } \\ \text { TWINS } & \text { Tank Waste Information System (database) } \\ \text { UDS } & \text { undissolved solids } \\ \text { URSILLA } & \text { Ultrasonic Interface Level Analyzer } \\ \text { WTP } & \text { Hanford Tank Waste Treatment and Immobilization Plant }\end{array}$





\section{Contents}

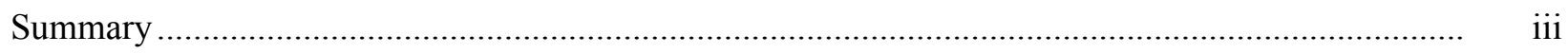

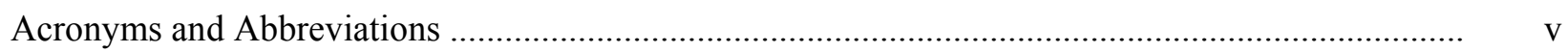

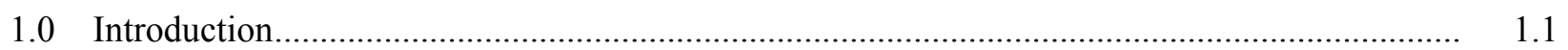

2.0 Distribution of Solids in AZ-101 Resulting from Mixer Pump Operation .............................. 2.1

2.1 AZ-101 Waste Properties and Tank Configuration ....................................................... 2.1

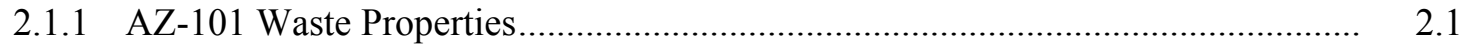

2.1.2 AZ-101 Tank Configuration ..................................................................... 2.5

2.2 Summary of AZ-101 Mixer Pump Operation.............................................................. 2.6

2.3 Suspended Solids Distribution in AZ-101 ................................................................ 2.7

2.3.1 AZ-101 Instrumentation Summary .............................................................. 2.7

2.3.2 AZ-101 Suspended UDS Distribution ............................................................ 2.8

3.0 AY-102 Waste Properties and Tank Configuration........................................................... 3.1

3.1.1 AY-102 Liquid and Undissolved Solids ...................................................... 3.1

3.1.2 AY-102 Tank Configuration.......................................................................... 3.2

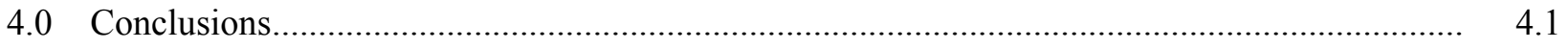

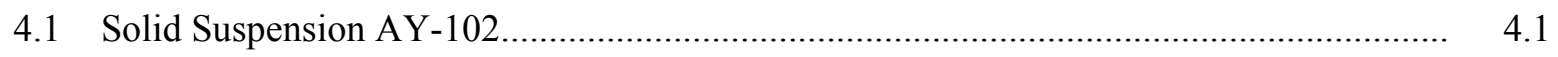

4.2 Solids Suspension for Hanford Waste …................................................................... 4.2

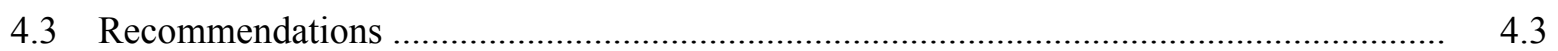

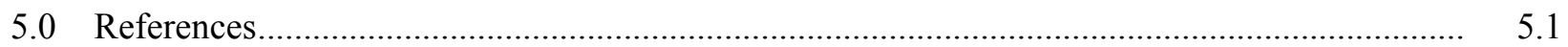

Appendix A: Gamma-Monitoring System Data ......................................................................... A.1 


\section{Figures}

2.1. Cumulative UDS Volume Fraction as Function of Settling Velocity for AZ-101 ................. 2.5

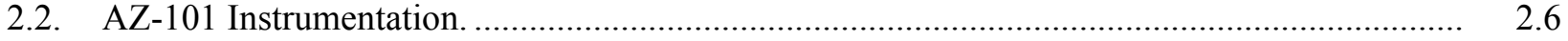

2.3. Gamma-Monitoring System Data from Cart A, Riser 15C, Settling Test Period, 0 to 45 Hours after Pump Shutdown (5-22, Carlson et al. 2001; Ordinate is Height Above Tank Bottom [inches])

2.4. Grab-Sample and Gamma Monitoring System Data Concurrent in Time............................... 2.11

2.5. Mass Fraction of UDS, ws, as a Function of Gamma Count ............................................... 2.13

2.6. Mass Fraction of UDS, $w_{S}$, as a Function of Gamma Count (close up) .................................. 2.14

2.7. Mass Fraction of UDS, $\mathrm{w}_{\mathrm{S}}$, as a Function of Gamma Count, Comparison of 0-Intercept

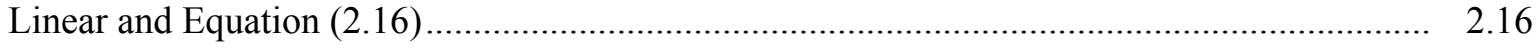

3.1. Cumulative UDS Volume Fraction as Function of Settling Velocity for AY-102 ................... 3.4

4.1. Cumulative UDS Volume Fraction as Function of Settling Velocity for Hanford Insoluble Solids, Case 3 PSDD, Wells et al. (2007)

\section{Tables}

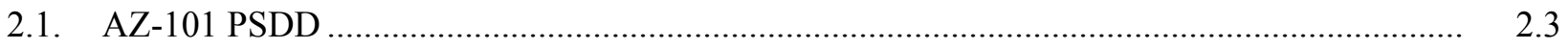

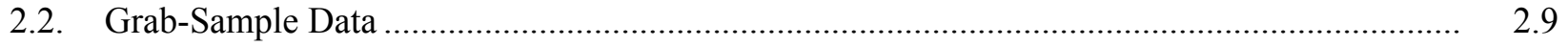

2.3. UDS Content and Gamma Count Rate …....................................................................... 2.12

2.4. Mass Fraction of UDS from Gamma Count, Approach 1, Equation (2.17) ........................... 2.17

2.5. Mass Fraction of UDS from Gamma Count, Approach 2, Equation (2.18) ........................... 2.17

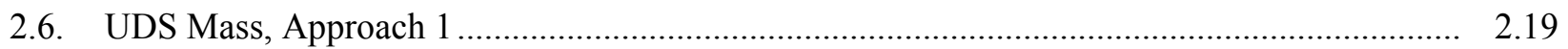

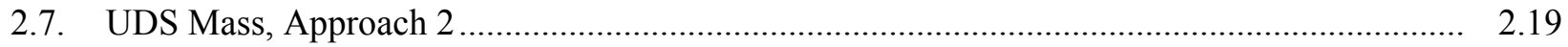

2.8. Average Mass Fraction of Solids Below Lowest Gamma Measurement Elevation,

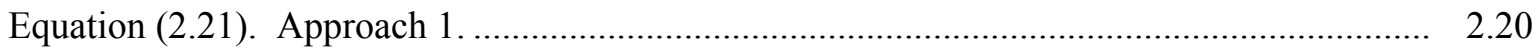

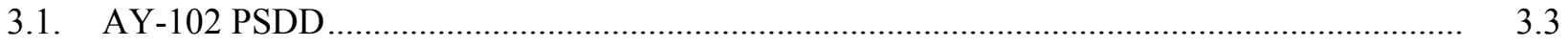




\subsection{Introduction}

The Hanford double-shell tank (DST) system provides the staging location for waste feed delivery to the Hanford Tank Waste Treatment and Immobilization Plant (WTP). Hall (2008) includes WTP acceptance criteria that describe physical and chemical characteristics of the waste that must be certified as acceptable before the waste is transferred from the DSTs to the WTP. The first stage of the DST Mixing and Sampling Demonstration Program is focused on defining the information gaps that must be filled to successfully demonstrate the capability of the baseline feed delivery concept to effectively mix, sample, and deliver DST waste to the WTP. Understanding the mixing performance of the baseline DST mixing systems is thus necessary to define the specific functional requirements of the DST sampling and feed transfer systems.

A significant amount of demonstration and computer modeling has been done at Hanford and Savannah River that focused on the effective cleaning radius of submerged pumps and their ability to mobilize waste solids off the bottom of the tank (Onishi and Wells 2004; Enderlin et al. 2003; Onishi et al. 2000; etc.). The rigorous characterization and acceptance requirements identified in ICD-19 dictate

a more thorough understanding of the suspended slurry that results from mobilizing the solids off the tank bottom.

The objective of this work is to describe the current level of understanding of the suspension of solids in Hanford DSTs while being mixed with the baseline configuration of two 300-horsepower mixer pumps. The mixer pump test conducted in AZ-101 during fiscal year 2000 provided the basis of understanding (Carlson et al. 2001). In Section 2, the mixer pump operation in AZ-101 is summarized, the waste properties and tank configuration are presented, and the quantity of suspended solids resulting from the AZ-101 mixer pump tests relative to homogenous mixing is evaluated.

AY-102 is the WTP commissioning feed tank, and the solids suspension therein is thus considered via the solids suspension performance of the baseline feed delivery mixer pumps in AZ-101. The waste properties and tank configuration of AY-102 are presented in Section 3. The AZ-101 and AY-102 waste properties and tank configurations are compared in Section 4, and the suspension of solids in AY-102 and more broadly to the Hanford waste in general for other WTP DST feed staging tanks is estimated. Recommendations for improving the understanding of solids suspension during mixer pump operation are provided. 



\subsection{Distribution of Solids in AZ-101 Resulting from Mixer Pump Operation}

The baseline configuration of two 300-horsepower mixer pumps was used to mobilize the sediment layer in AZ-101 during testing from 4/27/00 to 5/31/00 (Carlson et al. 2001). In Section 2.1, the AZ-101 waste properties and tank configuration are presented. The mixer pump operation and tank instrumentation pertinent to understanding solids suspension are summarized in Section 2.2, and solids suspension is evaluated in Section 2.3.

\subsection{AZ-101 Waste Properties and Tank Configuration}

Best-estimate values for AZ-101 waste properties at the time of the mixer pump test pertinent to the current evaluation have been determined based on the available data (Section 2.1.1). Given the different data sources, etc., significant digits are not considered, and all values are best-estimate approximations. The tank configuration is summarized in Section 2.1.2.

\subsubsection{AZ-101 Waste Properties}

The waste stored in AZ-101 before the mixer pump test consisted of a deep liquid layer overlaying a settled solids layer. The waste depth in AZ-101 was approximately 308 inches at the commencement of the mixer pump operations. Due to the failure of the pump column rupture disk in Mixer Pump 2, approximately 60,000 gallons of water were added during the operation of Mixer Pump 2, resulting in a final total waste depth of approximately 329 inches (Carlson et al. 2001). This water addition was approximately $7 \%$ by volume of the original liquid volume (supernate and interstitial liquid in the sediment, assumed to be synonymous).

\subsubsection{AZ-101 Liquid and Undissolved Solids}

The liquid density in AZ-101 at commencement of the mixer pump operations (subsequently referred to as the initial condition) was approximately $1.24 \mathrm{~g} / \mathrm{mL}$ (TWINS $^{(\mathrm{a})}$ ). Assuming that no solids dissolved, the water addition reduced the liquid density at the completion of the mixer pump operations (subsequently referred to as the final condition) to $1.22 \mathrm{~g} / \mathrm{mL}(\mathrm{Hu} 2007)$. The liquid temperature at the completion of the mixer pump operations was approximately $144^{\circ} \mathrm{F}$ (Carlson et al. 2001), and the dynamic viscosity of the AZ-101 liquid at that temperature was approximately $2 \mathrm{cP}$ (Callaway 2000).

The density of the initial sediment (undissolved solids [UDS] and interstitial liquid) was $1.62 \mathrm{~g} / \mathrm{mL}$ (Carlson et al. 2001). With a UDS density of $2.43 \mathrm{~g} / \mathrm{mL}$, ${ }^{(b)}$ the UDS content in the sediment can be estimated at $32 \%$ by volume, $48 \%$ by mass via

(a) Core sample Data from TWINS: Tank Waste Information System database.

http://twins.pnl.gov/twins3/twins.htm

(b) PNNL Letter Report to CH2M Hill: BE Wells. 2004. Evaluation of Waste Data for Rheological Models Used in Waste Pipeline Transfer Assessment. TWS05.001, Pacific Northwest National Laboratory, Richland, WA. 


$$
\phi_{\mathrm{S}}=\frac{\rho_{\mathrm{B}}-\rho_{\mathrm{L}}}{\rho_{\mathrm{S}}-\rho_{\mathrm{L}}}
$$

and

$$
\mathrm{w}_{\mathrm{S}}=\phi_{\mathrm{S}} \frac{\rho_{\mathrm{S}}}{\rho_{\mathrm{B}}}
$$

respectively, where $\rho_{\mathrm{B}}, \rho_{\mathrm{S}}$, and $\rho_{\mathrm{L}}$ denote the bulk, UDS, and liquid densities.

The initial sediment depth, $\mathrm{h}_{\mathrm{S}}$, was approximately 17.5 inches. ${ }^{\text {(a) }}$ Thus, the UDS mass in the tank is given by

$$
\mathrm{m}_{\mathrm{UDS}}=\mathrm{h}_{\mathrm{S}} \mathrm{A}_{\mathrm{T}} \rho_{\mathrm{B}} \mathrm{w}_{\mathrm{S}}
$$

with $\mathrm{A}_{\mathrm{T}}$ denoting the tank area, to be $141,565 \mathrm{~kg}$. The initial and final liquid masses are 3,909,277 $\mathrm{kg}$ and $4,128,202 \mathrm{~kg}$, respectively. A fully mixed condition in the tank at the end of the mixer pump test would thus have a UDS content of approximately $1.7 \%$ by volume, $3.3 \%$ by mass.

\subsubsection{AZ-101 Undissolved Solids Particulate Characterization}

The UDS particulate in AZ-101 can be characterized by a particle size and density distribution (PSDD). An AZ-101 PSDD was created according to the Case 3 approach of Wells et al. (2007). The Case 3 approach assigns the primary particulate density of the solid phase compounds (i.e., crystal density) to the particulate, independent of particle size. As such, solids particle density reduction (by agglomeration) below the primary crystal density is not accounted for. As discussed in Wells et al. (2007), this approach does not represent the actual phenomenon of Hanford particulate agglomeration, but it was selected because it provides an upper-bound for possible particle size and density, and it removes the significant uncertainty of quantifying the fractal dimension relating the agglomeration size and density. The presented PSDD developed using this approach is a representation of the AZ-101 UDS particulate. The discrepancy of the volume-weighted average UDS density from the PSDD of Table 2.1, $3.11 \mathrm{~g} / \mathrm{mL}$, and the UDS density in Section 2.1.1.1, $2.43 \mathrm{~g} / \mathrm{mL}$, is acknowledged.

The AZ-101 "minimal disturbance" PSD (Wells et al. 2007, Table A.4) was combined with the insoluble solid-phase compounds, volume fractions thereof, and crystal densities (Wells et al. 2007, Section 3.2). The resulting AZ-101 PSDD is provided in Table 2.1. Like the PSDDs of Wells et al. (2007), the AZ-101 PSDD in Table 2.1 is a 3-dimensional matrix of volume-based probability of each solid-phase compound in a particle-size distribution "bin" and its density in that bin. The PSDD bins represent the upper and lower size limit of the particles in each bin. For example, in Table 2.1, it can be seen that gibbsite $\left[\mathrm{Al}(\mathrm{OH})_{3}\right]$ comprises $75 \%$ of the solids particulate by volume, and gibbsite particles $>$ $7.74 \mu \mathrm{m}$ and less than or equal to $10 \mu \mathrm{m}$ have a density of $2.42 \mathrm{~g} / \mathrm{mL}$ and make up $3.6 \%$ of the solids by volume.

(a) Average of sludge weight data taken from publically released spreadsheet SVF-1112 all solids R0.xls provided via e-mail from JM Conner, CH2M Hill to BE Wells, PNNL, on 3/14/08. 
Table 2.1. AZ-101 PSDD

\begin{tabular}{|c|c|c|c|c|c|c|c|c|c|}
\hline \multirow{4}{*}{$\begin{array}{l}\text { Particle Size } \\
(\mu \mathrm{m})\end{array}$} & \multicolumn{9}{|c|}{ Solid Phase Compounds and Density $(\mathrm{g} / \mathrm{mL})$} \\
\hline & $\mathrm{Al}(\mathrm{OH})_{3}$ & $\mathrm{Fe}_{2} \mathrm{O}_{3}$ & $\mathrm{ZrO}_{2}$ & $\mathrm{Ca}_{5} \mathrm{OH}\left(\mathrm{PO}_{4}\right)_{3}$ & $\mathrm{Ni}(\mathrm{OH})_{2}$ & $\mathrm{Na}_{2} \mathrm{U}_{2} \mathrm{O}_{7}$ & $\mathrm{MnO}_{2}$ & $\mathrm{LaPO}_{4} \cdot 2 \mathrm{H}_{2} \mathrm{O}$ & $\mathrm{PuO}_{2}$ \\
\hline & 2.42 & 5.24 & 5.68 & 3.14 & 4.1 & 5.617 & 5.026 & 6.51 & 11.43 \\
\hline & \multicolumn{9}{|c|}{ Solid Volume Fraction } \\
\hline 0.22 & $3.8 \mathrm{E}-04$ & 7.7E-05 & $2.4 \mathrm{E}-05$ & $6.9 \mathrm{E}-06$ & $6.7 \mathrm{E}-06$ & $4.9 \mathrm{E}-06$ & $1.1 \mathrm{E}-06$ & $3.7 \mathrm{E}-06$ & $2.5 \mathrm{E}-08$ \\
\hline 0.28 & $9.1 \mathrm{E}-03$ & $1.9 \mathrm{E}-03$ & $5.7 \mathrm{E}-04$ & $1.7 \mathrm{E}-04$ & $1.6 \mathrm{E}-04$ & $1.2 \mathrm{E}-04$ & $2.7 \mathrm{E}-05$ & $9.0 \mathrm{E}-05$ & $6.0 \mathrm{E}-07$ \\
\hline 0.36 & $1.0 \mathrm{E}-02$ & $2.1 \mathrm{E}-03$ & $6.4 \mathrm{E}-04$ & $1.9 \mathrm{E}-04$ & $1.8 \mathrm{E}-04$ & $1.3 \mathrm{E}-04$ & $3.1 \mathrm{E}-05$ & $1.0 \mathrm{E}-04$ & $6.8 \mathrm{E}-07$ \\
\hline 0.46 & $1.3 \mathrm{E}-02$ & 2.7E-03 & $8.4 \mathrm{E}-04$ & $2.5 \mathrm{E}-04$ & $2.4 \mathrm{E}-04$ & $1.7 \mathrm{E}-04$ & $4.0 \mathrm{E}-05$ & $1.3 \mathrm{E}-04$ & 8.8E-07 \\
\hline 0.60 & $1.8 \mathrm{E}-02$ & $3.6 \mathrm{E}-03$ & $1.1 \mathrm{E}-03$ & $3.2 \mathrm{E}-04$ & 3.1E-04 & 2.3E-04 & 5.3E-05 & 1.7E-04 & 1.2E-06 \\
\hline 0.77 & $2.2 \mathrm{E}-02$ & $4.5 \mathrm{E}-03$ & $1.4 \mathrm{E}-03$ & $4.0 \mathrm{E}-04$ & $3.9 \mathrm{E}-04$ & $2.9 \mathrm{E}-04$ & $6.5 \mathrm{E}-05$ & $2.2 \mathrm{E}-04$ & $1.4 \mathrm{E}-06$ \\
\hline 1.00 & $5.4 \mathrm{E}-02$ & $1.1 \mathrm{E}-02$ & $3.4 \mathrm{E}-03$ & $9.9 \mathrm{E}-04$ & $9.6 \mathrm{E}-04$ & 7.0E-04 & $1.6 \mathrm{E}-04$ & $5.3 \mathrm{E}-04$ & $3.6 \mathrm{E}-06$ \\
\hline 1.29 & $5.1 \mathrm{E}-02$ & $1.0 \mathrm{E}-02$ & $3.2 \mathrm{E}-03$ & $9.3 \mathrm{E}-04$ & $9.0 \mathrm{E}-04$ & $6.6 \mathrm{E}-04$ & $1.5 \mathrm{E}-04$ & $5.0 \mathrm{E}-04$ & 3.4E-06 \\
\hline 1.67 & 4.6E-02 & $9.4 \mathrm{E}-03$ & $2.9 \mathrm{E}-03$ & $8.5 \mathrm{E}-04$ & $8.2 \mathrm{E}-04$ & $6.0 \mathrm{E}-04$ & $1.4 \mathrm{E}-04$ & 4.6E-04 & $3.0 \mathrm{E}-06$ \\
\hline 2.15 & $6.1 \mathrm{E}-02$ & $1.2 \mathrm{E}-02$ & $3.8 \mathrm{E}-03$ & $1.1 \mathrm{E}-03$ & $1.1 \mathrm{E}-03$ & 7.9E-04 & $1.8 \mathrm{E}-04$ & $6.0 \mathrm{E}-04$ & $4.0 \mathrm{E}-06$ \\
\hline 2.78 & $5.6 \mathrm{E}-02$ & $1.1 \mathrm{E}-02$ & $3.5 \mathrm{E}-03$ & $1.0 \mathrm{E}-03$ & $1.0 \mathrm{E}-03$ & 7.3E-04 & $1.7 \mathrm{E}-04$ & $5.6 \mathrm{E}-04$ & 3.7E-06 \\
\hline 3.59 & $6.0 \mathrm{E}-02$ & $1.2 \mathrm{E}-02$ & $3.8 \mathrm{E}-03$ & $1.1 \mathrm{E}-03$ & $1.1 \mathrm{E}-03$ & 7.9E-04 & $1.8 \mathrm{E}-04$ & $6.0 \mathrm{E}-04$ & 4.0E-06 \\
\hline 4.64 & $6.8 \mathrm{E}-02$ & $1.4 \mathrm{E}-02$ & 4.3E-03 & $1.3 \mathrm{E}-03$ & $1.2 \mathrm{E}-03$ & 8.9E-04 & $2.0 \mathrm{E}-04$ & $6.8 \mathrm{E}-04$ & 4.5E-06 \\
\hline 5.99 & $6.2 \mathrm{E}-02$ & $1.3 \mathrm{E}-02$ & $3.9 \mathrm{E}-03$ & $1.1 \mathrm{E}-03$ & $1.1 \mathrm{E}-03$ & $8.1 \mathrm{E}-04$ & $1.8 \mathrm{E}-04$ & $6.1 \mathrm{E}-04$ & 4.1E-06 \\
\hline 7.74 & $6.3 \mathrm{E}-02$ & $1.3 \mathrm{E}-02$ & $4.0 \mathrm{E}-03$ & $1.2 \mathrm{E}-03$ & $1.1 \mathrm{E}-03$ & 8.3E-04 & $1.9 \mathrm{E}-04$ & $6.3 \mathrm{E}-04$ & 4.2E-06 \\
\hline 10.00 & $3.6 \mathrm{E}-02$ & $7.3 \mathrm{E}-03$ & $2.2 \mathrm{E}-03$ & $6.6 \mathrm{E}-04$ & $6.3 \mathrm{E}-04$ & 4.7E-04 & $1.1 \mathrm{E}-04$ & $3.5 \mathrm{E}-04$ & $2.4 \mathrm{E}-06$ \\
\hline 12.92 & $3.5 \mathrm{E}-02$ & 7.2E-03 & $2.2 \mathrm{E}-03$ & $6.5 \mathrm{E}-04$ & $6.2 \mathrm{E}-04$ & 4.6E-04 & $1.0 \mathrm{E}-04$ & $3.5 \mathrm{E}-04$ & 2.3E-06 \\
\hline 16.68 & $3.2 \mathrm{E}-02$ & $6.6 \mathrm{E}-03$ & $2.0 \mathrm{E}-03$ & $6.0 \mathrm{E}-04$ & $5.8 \mathrm{E}-04$ & $4.2 \mathrm{E}-04$ & $9.7 \mathrm{E}-05$ & $3.2 \mathrm{E}-04$ & 2.1E-06 \\
\hline 21.54 & $2.8 \mathrm{E}-02$ & $5.7 \mathrm{E}-03$ & $1.8 \mathrm{E}-03$ & $5.2 \mathrm{E}-04$ & $5.0 \mathrm{E}-04$ & 3.7E-04 & 8.4E-05 & $2.8 \mathrm{E}-04$ & $1.8 \mathrm{E}-06$ \\
\hline 27.83 & 2.3E-02 & 4.7E-03 & $1.5 \mathrm{E}-03$ & 4.3E-04 & 4.1E-04 & $3.0 \mathrm{E}-04$ & $6.9 \mathrm{E}-05$ & 2.3E-04 & $1.5 \mathrm{E}-06$ \\
\hline 35.94 & 4.7E-03 & $9.5 \mathrm{E}-04$ & $2.9 \mathrm{E}-04$ & $8.6 \mathrm{E}-05$ & $8.3 \mathrm{E}-05$ & $6.1 \mathrm{E}-05$ & $1.4 \mathrm{E}-05$ & 4.6E-05 & $3.1 \mathrm{E}-07$ \\
\hline $\begin{array}{l}\text { Total Solid- } \\
\text { Phase Volume } \\
\text { Fraction }\end{array}$ & 0.75 & 0.15 & 0.047 & 0.014 & 0.013 & 0.010 & 0.002 & 0.007 & 0.00005 \\
\hline
\end{tabular}


The particle sizes and densities of the AZ-101 PSDD can be used in the settling velocity equation from Camenen (2008)

$$
\mathrm{U}_{\mathrm{T}}=\frac{v}{\mathrm{~d}}(\sqrt{15+\sqrt{\mathrm{Ga} / 0.3}}-\sqrt{15})^{2}
$$

where $\mathrm{Ga}$ is the Galileo number defined by

$$
\mathrm{Ga}=\frac{\left(\frac{\rho_{\mathrm{S}}}{\rho_{\mathrm{L}}}-1\right) \mathrm{gd}^{3}}{v^{2}},
$$

where $v$ is the kinematic viscosity of the fluid, and $d$ is the particle diameter.

The cumulative volume-based probability of the settling velocity of the AZ-101 insoluble solids, shown in Figure 2.1, is created using the settling velocities (Equation [2.4]) and volume fractions of Table 2.1. In Figure 2.1, the $50^{\text {th }}$ percentile (median) and $95^{\text {th }}$ percentile by volume of settling velocity are approximately $6.4 \mathrm{E}-6$ and $2.3 \mathrm{E}-4 \mathrm{~m} / \mathrm{s}$, respectively.

Comparing the initial in situ settling velocity of the solid-liquid interface during the settling test at the completion of the mixer pump test (see Section 2.2) from Carlson et al. ( 2001), approximately $6 \mathrm{E}-4 \mathrm{~m} / \mathrm{s}$, to the AZ-101 PSDD settling velocity of Figure 2.1 indicates that the in situ settling rate is greater than the $99^{\text {th }}$ percentile by volume of the PSDD settling velocity. This comparison, indicating that for in situ settling in AZ-101, the trailing edge of the solid-liquid interface (i.e., the slowest settling particulate) settles at the rate of the fastest settling particulate, was not expected.

A plausible solid-liquid interface settling velocity for homogenously suspended particulate can be obtained using the volume-weighted average settling velocity, defined by

$$
\overline{\mathrm{U}}=\frac{\sum_{\mathrm{i}=1}^{\mathrm{n}} \mathrm{x}_{\mathrm{i}} \mathrm{U}_{\mathrm{i}}}{\sum_{\mathrm{i}=1}^{\mathrm{n}} \mathrm{x}_{\mathrm{i}}}
$$

where $x_{i}$ is the volume fraction of solid $i$ relative to the total solid volume, $U_{i}$ is the settling velocity (Equation 2.4), and $\mathrm{n}$ is the number of entries in the PSDD (i.e., the number of particle-size bins multiplied by the number of solid-phase compounds). ${ }^{\text {(a) }}$

The volume-weighted average settling velocity of the AZ-101 PSDD (Table 2.1) is 4.3E-5, which is $7 \%$ of the in situ interface settling velocity of $6 \mathrm{E}-4 \mathrm{~m} / \mathrm{s}$. With regards to whether the AZ-101 particulate was homogenously suspended, it is pertinent to consider that the suspension was due to mixer pump

(a) To provide a representative volume-weighted average, a minimum i, dependent on the primary distribution, is required. 
operation. It is reasonable to assume that, if some of the initial sediment was not suspended (see Section 2.3), the UDS particulate that was suspended would have been the "lighter" material, i.e., the particulate with low settling velocities. Thus, the apparent discrepancy between the in situ and PSDDbased settling velocity may be even more pronounced than indicated by the comparison above.

These results from comparing settling velocities, given that the density of the particulate represented in the PSDD is conservatively high (see above), may imply that the particle sizes are biased low. Regardless, because the PSDD is defined as representative, and the PSDD for AY-102 is developed synonymously (Section 3), the AZ-101 and AY-102 waste characteristics were compared with the PSDDs as presented.

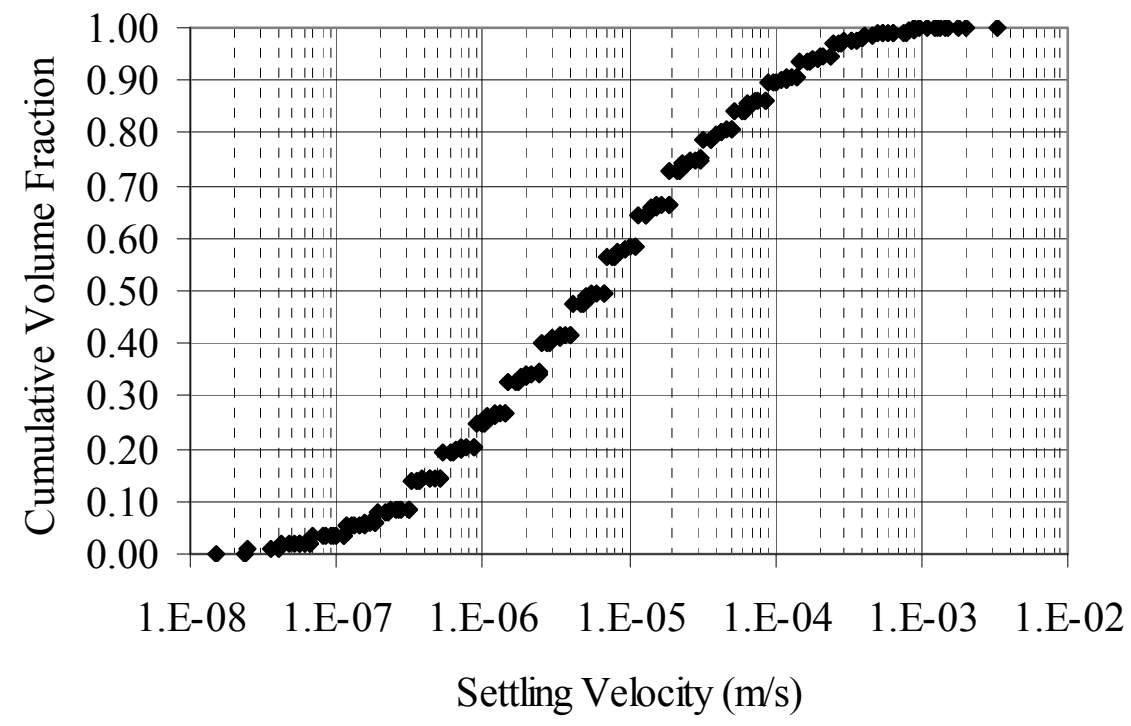

Figure 2.1. Cumulative UDS Volume Fraction as Function of Settling Velocity for AZ-101

\subsubsection{AZ-101 Tank Configuration}

Tank AZ-101 is a 37.5-ft radius 1,406,400-gallon DST with a maximum operating capacity of $1,159,600$ gallons (Barker 2003). The fill level at the maximum operating capacity is approximately 421 inches.

Aside from multi-instrument trees, etc., the internal tank structures with the most potential to impact UDS mobilization and suspension during mixer pump operation are the 22 airlift circulators (ALCs) that were intended to mix the waste by introducing a stream of air bubbles into 30-inch-diameter cylindrical tubes with a bottom elevation 30 inches above the tank bottom (Stewart et al. 2005). Fifteen of the ALCs extend to 294 inches above the tank bottom, and the remainder to 234 inches. One ALC is located at the center of the tank, 7 ALCs are equally spaced along the circumference at a radius at 14.5 feet from the tank center, and the remaining 14 are equally spaced along the circumference at a radius at 27 feet. 


\subsection{Summary of AZ-101 Mixer Pump Operation}

Two 300-horsepower Lawrence mixer pumps are installed in risers 1C (mixer pump 1) and 1A (mixer pump 2), see Figure 2.2. The mixer pumps take fluid in from 12 inches above the tank bottom and discharge it horizontally from two opposed 6-inch-diameter nozzles at 18 inches above the tank bottom.

Starting on 4/27/2000, mixer pump 1 was initially operated with the horizontal nozzle discharge at five fixed radial directions through a series of tests typically incrementally increasing in pump discharge speeds of nominally $725,1,000$, and 1,150 rpm. The pump was operated at each speed for approximately 3 hours. These rates approximately correspond to 7,100, 9,200, and 10,500 gpm total flow, or 12.3, 15.9, and $18.2 \mathrm{~m} / \mathrm{s}$ for each nozzle.

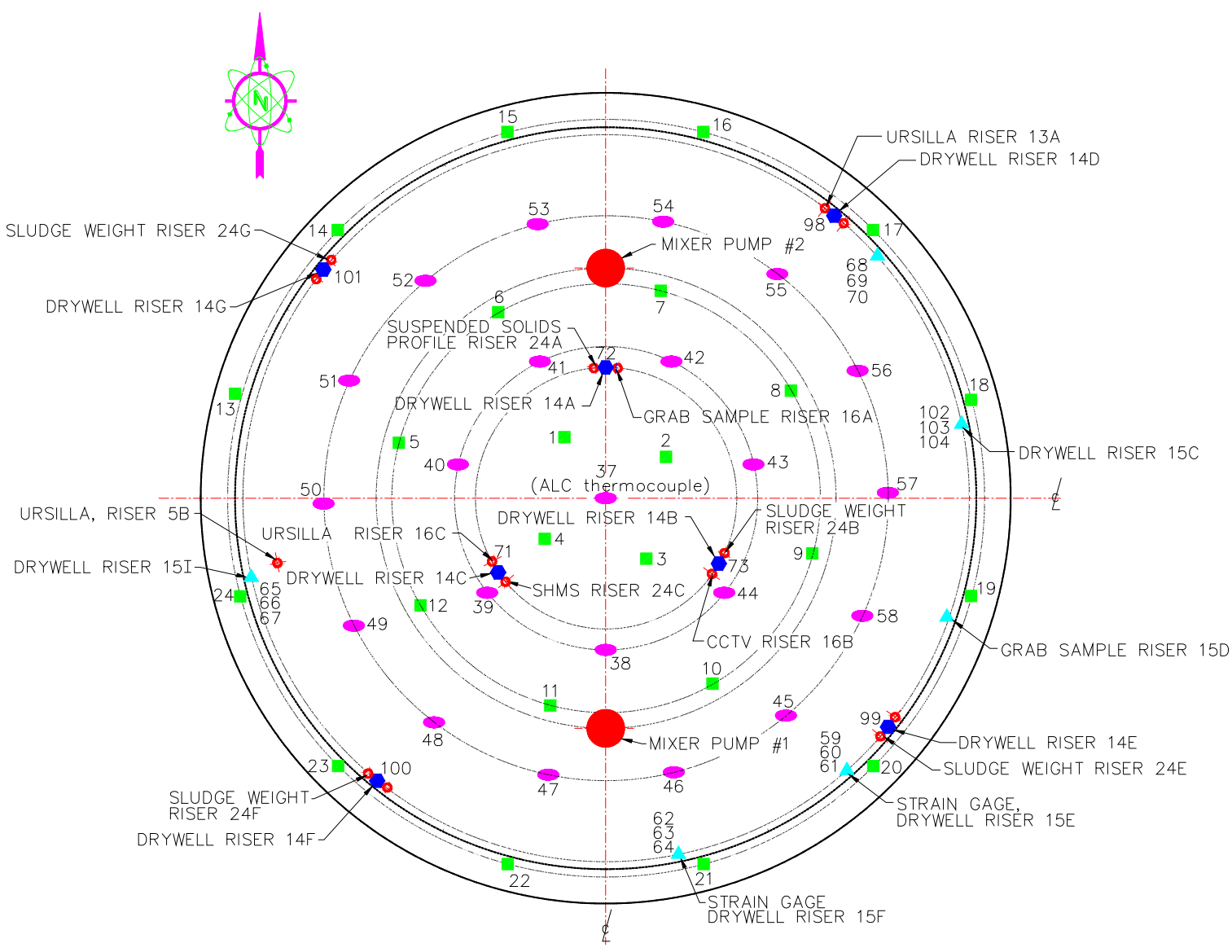

$\underline{241-A Z-101}$

PLAN VIEW

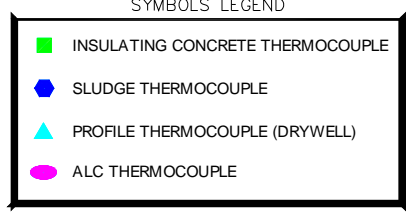

Figure 2.2. AZ-101 Instrumentation. Figure 3-4, Carlson et al. (2001). 
Mixer pump 1 was then operated in oscillation mode (horizontal nozzle discharge, $180^{\circ}$ pump rotation at 0.05 and $0.2 \mathrm{rpm}$ ) at each of the three nominal velocities totaling an operating period of almost 3.5 days. Mixer pumps 1 and 2 subsequently operated at equivalent rates, again ramping up at nominally $725,1,000$, and $1,150 \mathrm{rpm}$ over a total operating period of approximately 11 days.

The total flow for both mixer pumps during the test was nominally 285.5 million gallons, which is equivalent to 336 final AZ-101 waste volumes. The final operation of the mixer pumps, consisting of concurrent oscillatory operation $(0.05 \mathrm{rpm})$ for about 2.5 days at approximately $18 \mathrm{~m} / \mathrm{s}$, resulted in the re-circulation of 72 waste volumes through the mixer pumps. In this final operation, completed on 5/31/2000, mixer pump 1 was stopped at 12:51 PM because of operational issues, and mixer pump 2 was shut down at 4:20 PM.

Thermocouples located throughout the waste and in the tank floor indicate that 95 to $100 \%$ of the sediment was mobilized (Carlson et al. 2001). The time period immediately following the final operation of the mixer pumps is called the "settling test."

\subsection{Suspended Solids Distribution in AZ-101}

As reported in Section 2.2, 95 to $100 \%$ of the AZ-101 sediment was mobilized during the final mixer pump operation. The quantity of those mobilized solids that were suspended off the tank bottom by that operation is analyzed in this section.

The tank instrumentation, emphasizing those instruments pertinent to determining the UDS mobilization and suspension, is summarized in Section 2.3.1. The UDS distribution analysis and results are presented in Section 2.3.2.

\subsubsection{AZ-101 Instrumentation Summary}

AZ-101 mixer pump test instrumentation pertinent to the sediment mobilization and UDS suspension includes:

- Thermocouples (a thermocouple initially in the sediment is at a higher temperature than the supernate until the sediment at that location is mobilized)

- Ultrasonic Interface Level Analyzer (URSILLA) (uses ultrasonic ranging technique to measure vertical location of solid-liquid interface)

- Suspended Solids Profiler (SSP) (uses light reflectance to determine turbidity)

- Gamma-monitoring systems (detect radionuclides for concentration information)

- Grab samples (retrieved waste samples, analyzed for solid content, etc.)

- Sludge weights (essentially a metal weight on a tape measure, routinely used at Hanford to measure the solids level).

This instrumentation is located in AZ-101 as shown in the plan view tank diagram of Figure 2.2. The gamma-monitoring system was deployable in the drywell risers $14 \mathrm{~B}, 15 \mathrm{C}, 15 \mathrm{E}$, and $15 \mathrm{~F}$. Nine grabsample "events," consisting of eight $125-\mathrm{mL}$ grab samples taken incrementally throughout the waste depth, were obtained during testing. Grab-sample Events 5 through 9 were conducted after the final 
mixer pump operation. Grab-sample Event 6 was taken from riser 15D, and all other grab-sample events were taken in riser $16 \mathrm{~A}$.

The thermocouple data were used to quantify the extent of the solids mobilization. The URSILLA, grab-sample, and gamma data establish the solid-liquid interface settling rate data (see Section 2.1.1.2) with very good agreement between the instruments (Carlson et al. 2001). Carlson et al. (2001) report that although the available SSP data are consistent with respect to the solid-liquid interface of the URSILLA and grab-sample data, insufficient data are available to correlate the SSP data to solids concentration.

With the exception of the thermocouples, which had data recorded at 1-minute intervals throughout the testing, none of the above-listed instrumentation was operated during mixer pump operation. The gamma-monitoring system, grab-samples events, and sludge weight data evaluated for the quantity of UDS suspension reported in Section 2.3.2. Thus, these values represent the UDS suspension immediately following mixer pump operation.

\subsubsection{AZ-101 Suspended UDS Distribution}

The AZ-101 mixer pump test data, specifically those from the settling test (see Sections 2.2 and 2.3.1), were evaluated for the quantity of UDS suspension. The approach to correlating the UDS concentration to the gamma count is similar to that reported in Carlson et al. (2001). ${ }^{\text {(a) }}$ The current analysis develops the data set further as described in Section 2.3.2.1. The analysis approach was developed, and results are discussed in Section 2.3.2.2.

\subsubsection{Data Set}

The data set for quantifying the UDS concentration and gamma count from the AZ-101 mixer pump test is primarily based upon the analysis of the grab-sample event. The initial sediment condition is also considered.

Although gamma activity (counts per second, cps) data are available from two different instruments, Cart A and Cart B, only those data from Cart A were considered because only Cart A data were available for the settling test. Cart A was deployed in riser $15 \mathrm{~F}$ during the first mixer pump operations and $15 \mathrm{C}$ for the remainder of the testing (see Figure 2.2 for riser location). Gamma profiles from Cart A in riser 15C taken during the settling test immediately following the final mixer pump operation are provided in Figure 2.3. The gamma monitoring was analyzed such that the count rate (cps) increase with higher UDS concentration (Carlson et al. 2001). Profile (1) of Figure 2.3, taken during the settling test from 0 to 73 minutes after cessation of mixer pump operation, shows a relatively uniform counting rate from approximately 38 to 290 inches, indicating a uniform distribution of solids. The data of Figure 2.3 are provided in tabular form Appendix A. Also included are data from pre-mixer pump conditions and those gamma scans with sufficient data to be associable with grab-sample Event 8.

Grab-sample Events 5 through 7 were taken at similar elevations in the tank and during the same time period as Profiles (1) through (5) of Figure 2.3. The grab-sample analysis data from Event 5 summarized in Carlson et al. (2001) were taken from Bell (2001). No chemical or radiochemical analyses were

(a) PJ Certa, September 13, 2001. 241-AZ-101 Mixer Pump Test Solids Profiles. CH2M HILL Interoffice Memo, 7G300-01-DJW-008. CH2M HILL Hanford Group Inc., Richland, WA. 
performed on the samples from Event 6 (Bell 2000), nor for Events 7 and 9 (Bell 2001). Data for analyzed samples from Events 5 and 8 that contained appreciable solids (equal to or greater than 0.766 $\mathrm{g} / \mathrm{L}$, Carlson et al. 2001) are provided in Table 2.2. The mass fraction of solids in the grab sample, $\mathrm{w}_{\mathrm{SG}}$, was computed from

$$
\mathrm{w}_{\mathrm{SG}}=\left(1-\frac{1-\mathrm{w}_{\mathrm{SCS}}}{\mathrm{w}_{\mathrm{HCL}}}\right) \frac{\mathrm{V}_{\mathrm{CS}}}{\mathrm{V}_{\mathrm{B}}}
$$

where $\mathrm{w}_{\mathrm{SCS}}$ and $\mathrm{w}_{\mathrm{HCL}}$ are the mass fraction of solids in the centrifuged solids and water in the centrifuged liquid, respectively, $\mathrm{V}_{\mathrm{CS}}$ is the volume of centrifuged solids, and $\mathrm{V}_{\mathrm{B}}$ is the bulk grab-sample volume. Figure 2.4 shows the time and elevation of the concurrent grab samples and gamma scans during the settling test.

Table 2.2. Grab-Sample Data

\begin{tabular}{ccccccccc}
\hline & \multicolumn{9}{c}{ Bell (2001) } & \multicolumn{3}{c}{ Eqn. (2.7) } \\
\cline { 2 - 9 } $\begin{array}{c}\text { Sample } \\
\text { Number }\end{array}$ & Date & Time & (in.) $^{(\mathbf{a})}$ & $\mathrm{w}_{\text {SCS }}$ & $\mathrm{w}_{\text {HCL }}$ & $\begin{array}{c}\mathrm{V}_{\mathrm{CS}} \\
(\mathrm{mL})\end{array}$ & $\begin{array}{c}\mathrm{V}_{\mathrm{B}} \\
(\mathrm{mL})\end{array}$ & $\mathrm{w}_{\mathrm{SG}}$ \\
\hline 1AZ-00-35 & $5 / 31 / 00$ & $16: 31$ & 6 & 0.545 & 0.6998 & 5.86 & 123.4 & 0.017 \\
1AZ-00-36 & $5 / 31 / 00$ & $16: 40$ & 48 & 0.512 & 0.713 & 5.08 & 128.2 & 0.013 \\
1AZ-00-37 & $5 / 31 / 00$ & $17: 04$ & 90 & 0.513 & 0.7162 & 5.01 & 130.5 & 0.012 \\
1AZ-00-38 & $5 / 31 / 00$ & $17: 16$ & 132 & 0.575 & 0.7051 & 3.22 & 92.24 & $0.009^{(b)}$ \\
1AZ-00-39 & $5 / 31 / 00$ & $17: 41$ & 174 & 0.516 & 0.708 & 3.2 & 125 & 0.008 \\
1AZ-00-40 & $5 / 31 / 00$ & $18: 04$ & 216 & 0.559 & 0.7087 & 0.2 & 128.2 & 0.001 \\
1AZ-00-67 & $6 / 1 / 00$ & $17: 12$ & 6 & 0.52 & 0.7054 & 35.09 & 118.8 & 0.094 \\
\hline
\end{tabular}

(a) Elevation from Carlson et al. (2001).

(b) Approximately $1 / 3$ of the sample liquid was spilled and lost before analysis (Carlson et al. 2001). The presented result is "corrected" for liquid loss. 

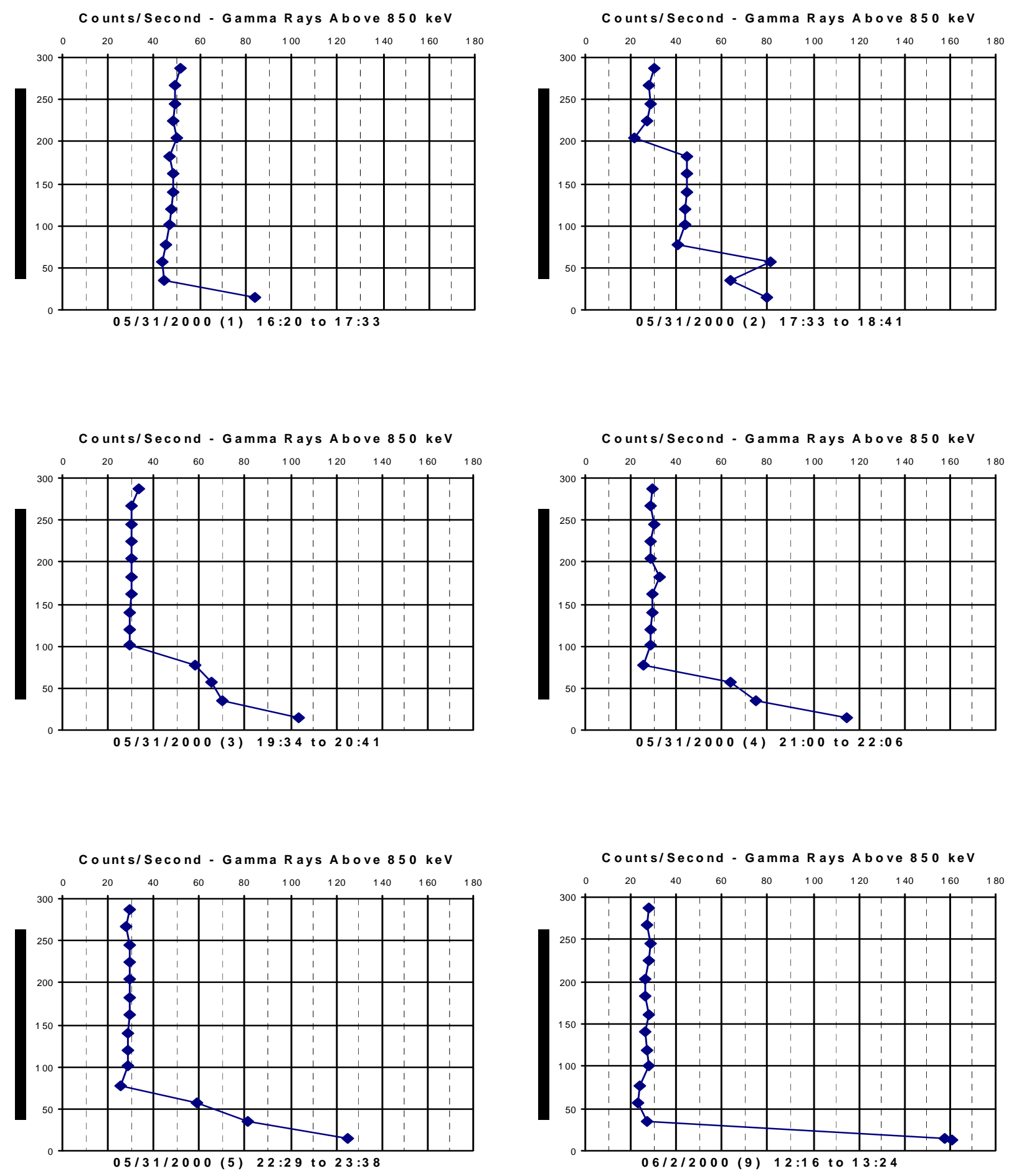

Figure 2.3. Gamma-Monitoring System Data from Cart A, Riser 15C, Settling Test Period, 0 to 45 Hours after Pump Shutdown (Figure 5-22, Carlson et al. 2001; Ordinate is Height Above Tank Bottom [inches]) 


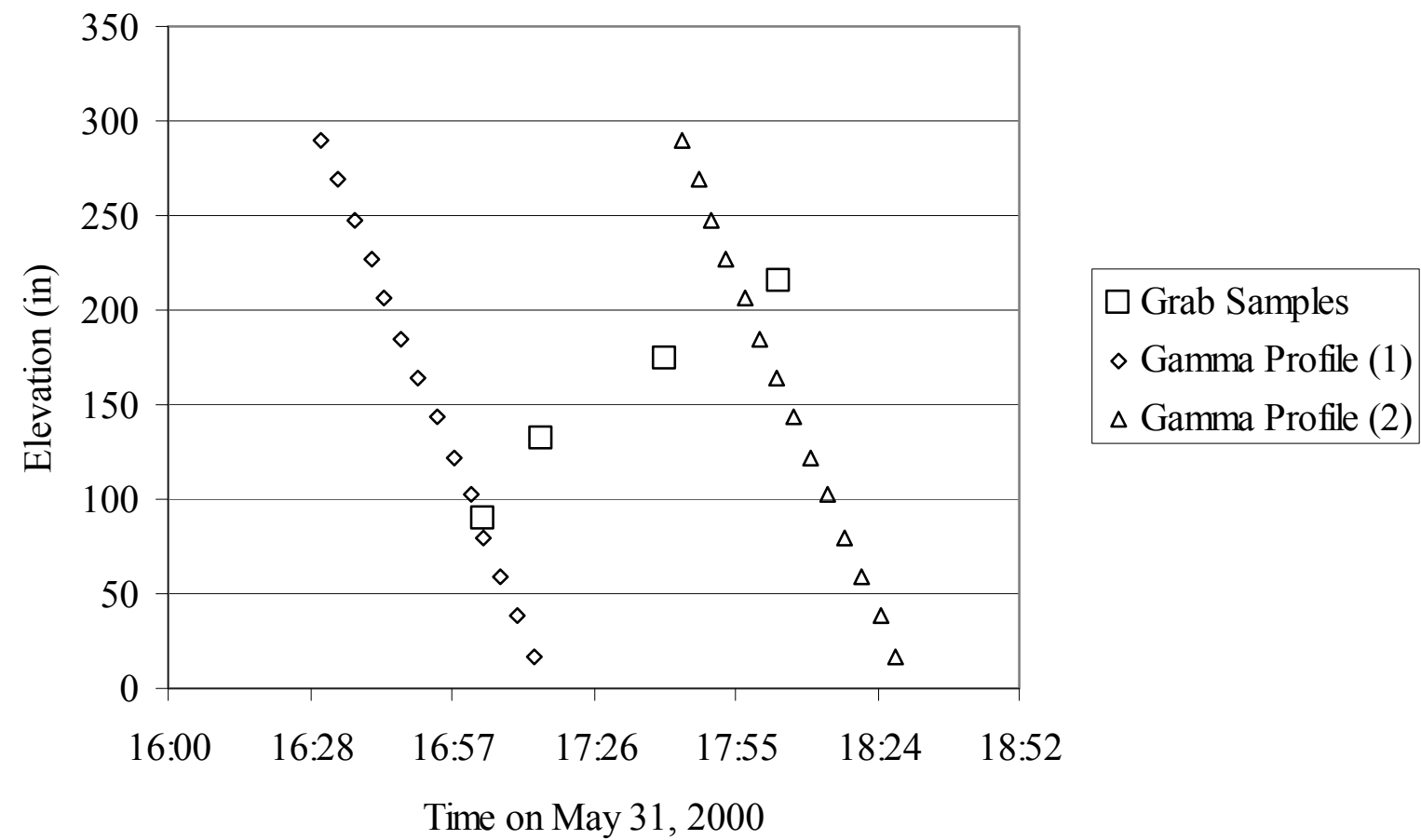

Figure 2.4. Grab-Sample and Gamma Monitoring System Data Concurrent in Time. Gamma Profile Numbers Correspond to Figure 2.3.

Using the mass fractions of water in centrifuged solids and liquids to determine the UDS density has been shown to over-predict the chemically plausible density (Onishi et al. 2002 and TWS05.001 ${ }^{(a)}$ ). These results may suggest that the UDS content of the grab samples of Table 2.2 (synonymous with Bell 2001) are biased low.

Comparison of the UDS density computed via

$$
\rho_{\mathrm{S}}=\frac{\rho_{\mathrm{B}}\left(1-\frac{1-\mathrm{w}_{\mathrm{SCS}}}{\mathrm{w}_{\mathrm{HCL}}}\right)}{1-\frac{\rho_{\mathrm{B}}}{\rho_{\mathrm{L}}}\left(\frac{1-\mathrm{w}_{\mathrm{SCS}}}{\mathrm{w}_{\mathrm{HCL}}}\right)}
$$

from the data of Table 2.2 and Bell (2001) to the UDS density of $2.43 \mathrm{~g} / \mathrm{mL}$, given in Section 2.1, indicates that the mass fraction of solids in the grab samples may be 7 to $35 \%$ low depending on which sample is considered. Given the lack of definitive data, there was no attempt in the current analysis to reconcile potential differences, and the data of Table 2.2 were used as reported.

(a) PNNL Letter Report to CH2M Hill: Wells BE. 2004. Evaluation of Waste Data for Rheological Models Used in Waste Pipeline Transfer Assessment. TWS05.001, Pacific Northwest National Laboratory, Richland, WA. 
By interpolating in elevation and time, concurrent solids-content information from the grab samples, Table 2.2, and the gamma data, Appendix A, as illustrated in Figure 2.4 can be developed, Table 2.3. Grab-sample data from 1AZ-00-35 and 1AZ-00-36 cannot be correlated with gamma cps, given the disparity in time, and, for the 6-inch sample, the elevation, Figure 2.4. The data for sample 1AZ-00-67 have the same elevation issue. All other data of Table 2.2 were considered.

In Table 2.3, data points 1 and 2 are from pre-mixer pump conditions on 4/27/00 and 4/31/00. The median gamma activity for the supernatant liquid $\left(\mathrm{w}_{\mathrm{S}}=0\right)$ is the median of the pre-mixer pump data above the initial sediment height. The gamma activity for the UDS content in the sediment, $\mathrm{w}_{\mathrm{S}}=0.48$, Section 2.1.1.1, is the median of the data at 16 inches elevation. The latter data point is subject to relatively significant uncertainty given that the solids content is the average throughout the sediment, and the gamma datum is from essentially the very top of the sediment.

The post-test supernatant liquid cps, data point 3, is the median of the $6 / 2 / 00$ data 38 inches in elevation and above. The solid-liquid interface data of the URSILLA, grab-sample, and gamma data indicate that this measurement does not include solids (Section 2.3.1). The change in liquid gamma activity from the pre-test condition to the settling test condition is attributed to the water addition over the test period (Section 2.1.1).

The gamma activity for data points 4 and 7 are liner interpolations in elevation only. For example, for data point 7, the gamma activity at approximately 17:02 and 17:04, 5/31/00 (Profile 1 of Figure 2.3 and Figure 2.4), from approximate elevations of 103 and 80 inches, respectively, was interpolated to the 90-inch elevation of sample 1AZ-00-37 of grab-sample Event 5, taken at 17:04 (see Figure 2.4).

Data points 5 and 6 were determined from the grab-sample data and linear interpolation of the gamma activity with elevation and then time to that of the pertinent grab sample. For data point 5, it can be observed from Figure 2.4 that sample 1AZ-00-39 (174 inches elevation at 17:41) is bounded in elevation and time by gamma Profiles 1 and 2 of Figure 2.3. Linear interpolation with the elevation between the gamma activity at 164 and 185 inches to 174 inches provides $48 \mathrm{cps}$ at an average time of 16:49 and $44 \mathrm{cps}$ at an average time of 18:01. Interpolation to 17:41 results in $45 \mathrm{cps}$. Data point 6 was developed similarly.

Table 2.3. UDS Content and Gamma Count Rate

\begin{tabular}{lclcc}
\hline Test Condition & Data Point Number & ws & Gamma (cps) & UDS Gamma $^{(\mathbf{a})}(\mathrm{cps})$ \\
\hline Pre-Test & 1 & 0.0 & 34 & 0 \\
& 2 & 0.48 & 300 & 266 \\
\hline Settling Test & 3 & 0.0 & 27 & 0 \\
& 4 & 0.001 & 31 & 4 \\
& 5 & 0.008 & 45 & 18 \\
6 & 0.009 & 47 & 20 \\
& 7 & 0.012 & 46 & 19 \\
\hline
\end{tabular}

(a) The UDS gamma count has the contribution of the liquid for the applicable test condition removed. 


\subsubsection{Data Analysis and Discussion}

The data of Table 2.3 were used to correlate the UDS concentration to the gamma count rate. As indicated in Carlson et al. (2001), the functionality of the response in gamma activity to solids concentration is unknown. Linear functionalities are presented and compared to an approximated radiation detection approach.

The data from the initial period of the settling test used to develop the data of Table 2.3 was the period of specific interest (see Section 2.3.1; no data were available during mixing, and thus the settling test data were evaluated). Thus, the exact functionality of the relationship is not as critical to the accuracy of the results; no extrapolation is required. The uncertainty of the data themselves, not the functionality of the relation, may therefore be expected to have the most significant impact on the accuracy of the results.

Two regions of Table 2.3 data were fit using linear least-squares regression. "Approach 1 " developed fits for data points 2 through 7, while "Approach 2" used data points 3 through 7. Approach 2 exclusively uses the grab-sample data. The fits for each approach are shown in Figure 2.5. The relative fit for the grab-sample data points is highlighted in Figure 2.6 (close-up of Figure 2.5). The two different approaches were developed given the uncertainty of data point 2 as described above. The data of $0 \mathrm{cps}$, $\mathrm{w}_{\mathrm{S}}=0$, is physical. Thus, fits with the intercept set to zero are also included in Figure 2.5 and Figure 2.6. For Approach 2, the grab-sample data, the difference is negligible.

The fits for Approach 1 over-predict the grab-sample mass fraction data by factors of approximately 2 to 3.5. Given the intended application as described above and the poor fit to the grab-sample data, the Approach 1 fits may not be appropriate. Conversely, Approach 2 is shown to significantly under-predict the estimated solids concentration for data point 2 . The validity of inclusion or exclusion of data point 2 was evaluated with a mass balance of the UDS in the tank following comparison of the 0 -intercept linear fits to that from the radiation-detection approach.

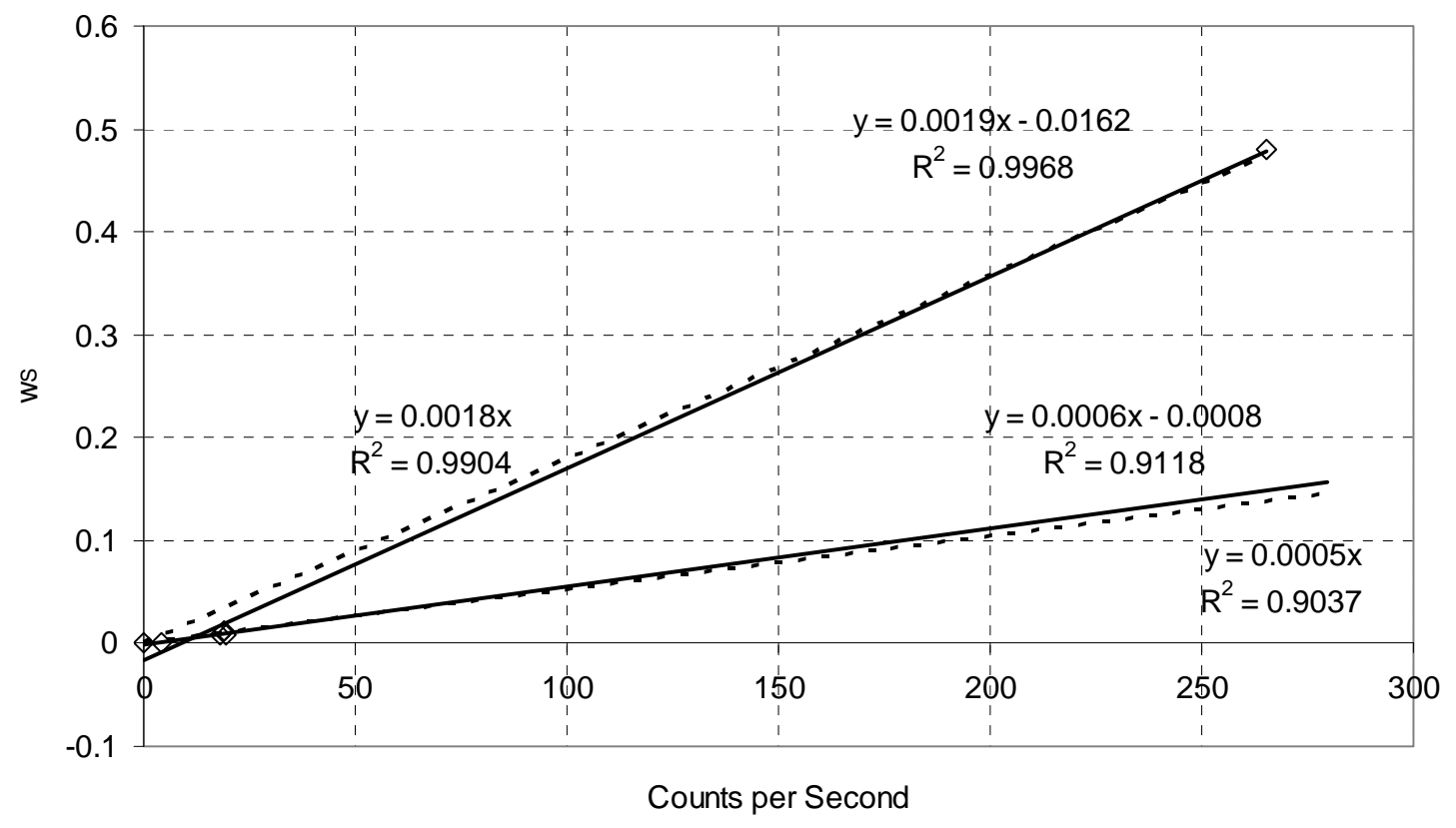

Figure 2.5. Mass Fraction of UDS, $\mathrm{w}_{\mathrm{S}}$, as a Function of Gamma Count 


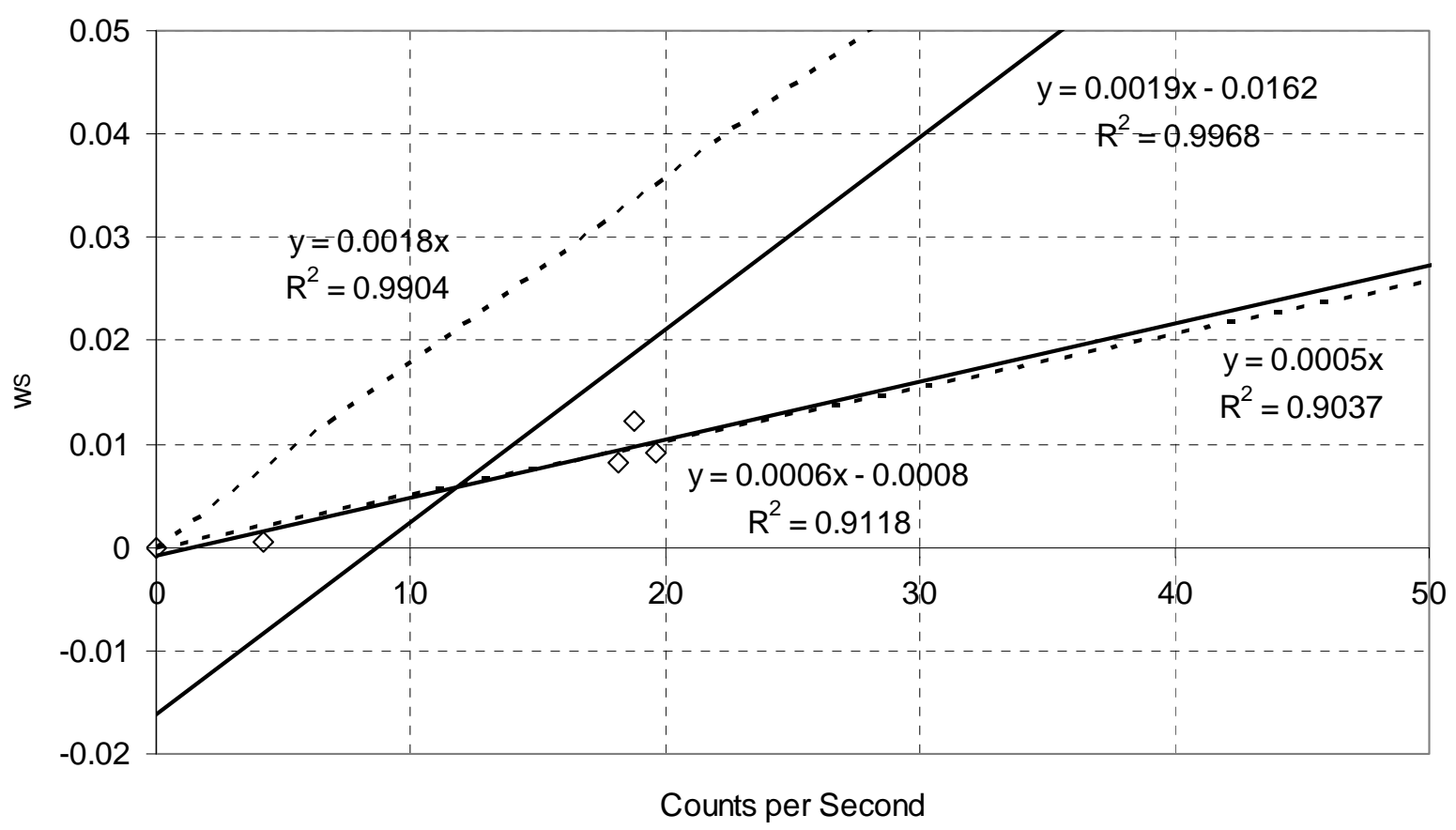

Figure 2.6. Mass Fraction of UDS, $w_{S}$, as a Function of Gamma Count (close up)

Synonymous with the 0-intercept linear fits of Approaches 1 and 2, it can be assumed that for a higher concentration of radioactive solids, the activity (cps) linearly increases. The activity emitted by a radioactive solid, $\mathrm{A}_{\text {emit }}$, and observed, $\mathrm{A}_{\mathrm{obs}}$, may thus be expressed as

$$
\mathrm{A}_{\mathrm{obs}}=\mathrm{A}_{\mathrm{emit}}=\lambda \mathrm{N}_{\mathrm{rad}}
$$

where $\lambda$ is the decay constant, and $\mathrm{N}_{\mathrm{rad}}$ is the number of radioactive atoms (Knoll 2000). With the mass of the UDS, $\mathrm{m}_{\mathrm{S}}$, given by

$$
\mathrm{m}_{\mathrm{S}} \equiv \mathrm{N}_{\mathrm{rad}} \frac{\mathrm{A}_{\mathrm{rad}}}{\mathrm{N}_{\mathrm{A}}} \frac{\mathrm{m}_{\mathrm{S}}}{\mathrm{m}_{\text {Srad }}}
$$

where $A_{\text {rad }}$ is the mass ( $a m u$ ) of the radioactive solid, $N_{A}$ is Avogadro's number, and $m_{\text {Srad }}$ is the mass of the radioactive solid. Equation (2.9) can then be written as

$$
\mathrm{A}_{\mathrm{obs}}=\mathrm{A}_{\mathrm{emit}}=\mathrm{Cm}_{\mathrm{S}}
$$

where $\mathrm{C}$ is a constant. The mass of solids is $\mathrm{m}_{\mathrm{S}}=\mathrm{w}_{\mathrm{S}} \mathrm{m}_{\mathrm{B}} ; \mathrm{m}_{\mathrm{B}}$ is the total mass of solid and liquid. Thus, Equation (2.11) can be written in terms of the mass fraction of solids as

$$
\mathrm{A}_{\mathrm{obs}}=\mathrm{A}_{\mathrm{emit}}=\mathrm{kW}_{\mathrm{S}}
$$

where $\mathrm{k}$ is a constant. 
It is expected that with more solids, there will be a higher probability for self-absorption. This phenomenon is approximated by considering that the transmission, $\mathrm{T}$, can be expressed as

$$
\mathrm{T}=\mathrm{e}^{-\frac{\mu}{\rho_{\mathrm{B}}} \rho_{\mathrm{B}} \mathrm{t}}
$$

where $\mu$ is the linear attenuation coefficient, and $t$ is the thickness of the absorbing material (Knoll 2000). If it is assumed that $\mu=\mathrm{c} \rho_{\mathrm{B}}$ (c is a constant), the summation of the transmission from the radioactive solids over the maximum range of the detector, $\mathrm{t}_{\max }$, may be expressed as

$$
\mathrm{T}=\int_{0}^{\mathrm{t}_{\max }} \mathrm{e}^{-\mathrm{a} \rho_{\mathrm{B}} \mathrm{t}} \mathrm{dt}=\frac{1}{\mathrm{a} \rho_{\mathrm{B}}}\left(1-\mathrm{e}^{-\mathrm{a} \rho_{\mathrm{B}} \mathrm{t}_{\max }}\right)
$$

Then

$$
\mathrm{A}_{\mathrm{obs}}=\mathrm{A}_{\text {emit }} \mathrm{T}
$$

With Equation (2.12),

$$
A_{\text {obs }}=\mathrm{kw}_{\mathrm{S}} \frac{1}{\mathrm{a} \rho_{\mathrm{B}}}\left(1-\mathrm{e}^{-\mathrm{a} \rho_{\mathrm{B}} \mathrm{t}_{\max }}\right)
$$

The gamma probe was deployed in the center of drywells, which have a diameter of 6 inches $(0.1524 \mathrm{~m}){ }^{(a)}{ }^{\left({ }^{2}\right.} \mathrm{t}_{\max }$ is un-physically decreased to less than $0.0762 \mathrm{~m}$ (distance from probe to drywell wall), the best fit of Equation (2.16) approaches the 0-intercept linear function for both Approaches 1 and 2. The fit with $t_{\max }$ set to the unphysical limit of the tank diameter, $22.86 \mathrm{~m}$, is essentially equivalent to that with $\mathrm{t}_{\max }$ set to $0.0762 \mathrm{~m}$. Thus, $\mathrm{t}_{\max }$ is approximated at $0.0762 \mathrm{~m}$.

Equation (2.16) was fit to the data of Approaches 1 and 2 via a least-squares regression optimizing the predicted to the measured cps by adjusting constants $\mathrm{k}$ and $\mathrm{a}$. The resultant fits are provided in Figure 2.7.

Given that there is minimal difference in the Equation (2.16) fits to the 0-intercept linear fits, significant approximating assumptions are required to achieve Equation (2.16), and a solution for $\mathrm{w}_{\mathrm{S}}$ from Equation (2.16) is challenging $\left[\rho_{\mathrm{B}}=\mathrm{f}\left(\mathrm{w}_{\mathrm{S}}, \rho_{\mathrm{S}}, \rho_{\mathrm{L}}\right)\right]$; see Equation $(2.20)^{(\mathrm{b})}$ - the 0 -intercept linear fits are analyzed further.

(a) Tank AZ-101 Drywell Temperature Probe Assy \& Install, Drawing Number H-2-79229, Rev. 1.

(b) It is noted that the Lambert W function can be used to solve Equation (2.16) for $\mathrm{w}_{\mathrm{s}}$. 


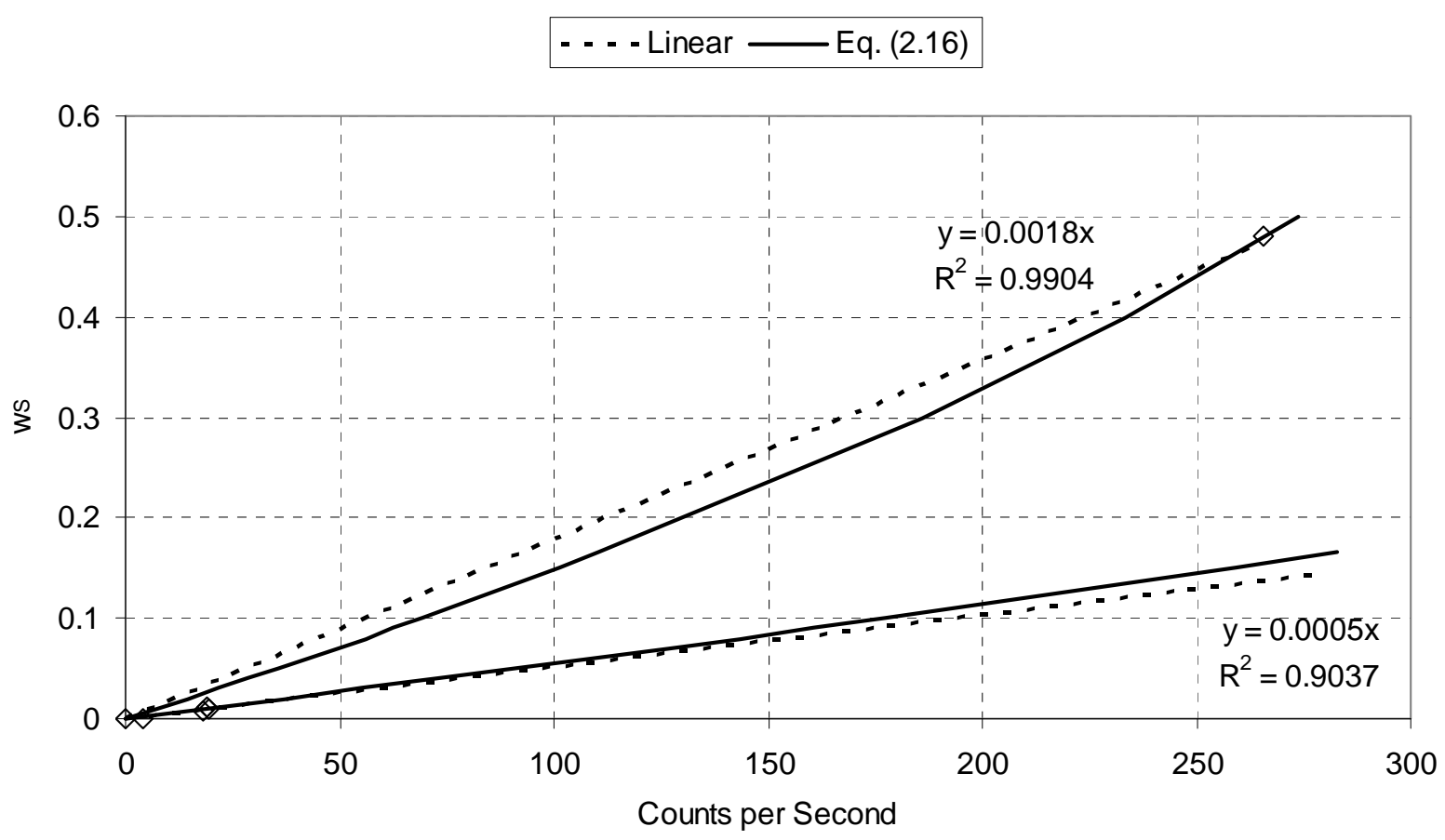

Figure 2.7. Mass Fraction of UDS, $\mathrm{w}_{\mathrm{S}}$, as a Function of Gamma Count, Comparison of 0-Intercept Linear and Equation (2.16)

The mass fraction results of the application of the Approach 10 -intercept linear fit

$$
\mathrm{w}_{\mathrm{S}}=0.0018 \mathrm{cps}
$$

and the Approach 2 0-intercept linear fit

$$
\mathrm{w}_{\mathrm{S}}=0.0005 \mathrm{cps}
$$

to selected gamma scan data from Appendix A (liquid condition, $27 \mathrm{cps}$, data point 3, Table 2.3, subtracted from each reading) are provided in Table 2.4 and Table 2.5, respectively. As expected, comparing the predicted $\mathrm{w}_{\mathrm{S}}$ to the measured $\mathrm{w}_{\mathrm{S}}$ for data points $4,5,6$, and 7 of Table 2.3 shows that Approach 1 over-predicts by factors of up to 6 . Approach 1 also indicates solids loadings, albeit very low, at elevations the URSILLA and grab samples indicated were solids free. 
Table 2.4. Mass Fraction of UDS from Gamma Count, Approach 1, Equation (2.17)

\begin{tabular}{ccccccccc}
\hline $\begin{array}{c}\text { Elevation } \\
\text { (in.) }\end{array}$ & \multicolumn{7}{c}{$\mathrm{w}_{\mathrm{S}}$, Gamma Scan Identification \# (see App. A, 5/31/00 to 6/2/00) } \\
\cline { 2 - 9 } & 5 & 6 & 7 & 8 & 9 & 10 & 11 & 12 \\
\hline 290 & 0.043 & 0.006 & 0.012 & 0.004 & 0.004 & 0.004 & 0.001 & 0.002 \\
269 & 0.040 & 0.002 & 0.006 & 0.003 & 0.002 & 0.000 & 0.000 & 0.000 \\
248 & 0.039 & 0.003 & 0.006 & 0.006 & 0.005 & 0.001 & 0.001 & 0.003 \\
227 & 0.037 & 0.000 & 0.006 & 0.003 & 0.004 & 0.001 & 0.000 & 0.001 \\
206 & 0.042 & 0.000 & 0.005 & 0.003 & 0.004 & 0.002 & 0.002 & 0.000 \\
185 & 0.035 & 0.031 & 0.006 & 0.009 & 0.004 & 0.003 & 0.000 & 0.000 \\
164 & 0.039 & 0.031 & 0.006 & 0.004 & 0.005 & 0.001 & 0.001 & 0.002 \\
143 & 0.038 & 0.031 & 0.005 & 0.004 & 0.004 & 0.016 & 0.000 & 0.000 \\
122 & 0.036 & 0.030 & 0.004 & 0.003 & 0.003 & 0.001 & 0.000 & 0.000 \\
103 & 0.036 & 0.030 & 0.004 & 0.002 & 0.002 & 0.000 & 0.000 & 0.002 \\
80 & 0.032 & 0.024 & 0.056 & 0.000 & 0.000 & 0.000 & 0.000 & 0.000 \\
59 & 0.029 & 0.097 & 0.068 & 0.065 & 0.057 & 0.000 & 0.000 & 0.000 \\
38 & 0.032 & 0.066 & 0.078 & 0.085 & 0.097 & 0.030 & 0.020 & 0.000 \\
17 & 0.102 & 0.095 & 0.137 & 0.157 & 0.175 & 0.202 & 0.199 & 0.234 \\
16 & NA $^{(\text {b) }}$ & NA & NA & NA & NA & 0.205 & 0.207 & NA \\
\hline
\end{tabular}

(a) 101 inches for gamma scans 10,11 , and 12 .

(b) NA-no data taken at this elevation.

Table 2.5. Mass Fraction of UDS from Gamma Count, Approach 2, Equation (2.18)

\begin{tabular}{ccccccccc}
\hline $\begin{array}{c}\text { Elevation } \\
\text { (in.) }\end{array}$ & \multicolumn{7}{c}{$\mathrm{w}_{\mathrm{S}}$, Gamma Scan Identification \# (see App. A, 5/31/00 to 6/2/00) } \\
\cline { 2 - 9 } & 5 & 6 & 7 & 8 & 9 & 10 & 11 & 12 \\
\hline 290 & 0.013 & 0.002 & 0.003 & 0.001 & 0.001 & 0.001 & 0.000 & 0.001 \\
269 & 0.012 & 0.001 & 0.002 & 0.001 & 0.001 & 0.000 & 0.000 & 0.000 \\
248 & 0.011 & 0.001 & 0.002 & 0.002 & 0.001 & 0.000 & 0.000 & 0.001 \\
227 & 0.011 & 0.000 & 0.002 & 0.001 & 0.001 & 0.000 & 0.000 & 0.000 \\
206 & 0.012 & 0.000 & 0.002 & 0.001 & 0.001 & 0.001 & 0.000 & 0.000 \\
185 & 0.010 & 0.009 & 0.002 & 0.003 & 0.001 & 0.001 & 0.000 & 0.000 \\
164 & 0.011 & 0.009 & 0.002 & 0.001 & 0.001 & 0.000 & 0.000 & 0.001 \\
143 & 0.011 & 0.009 & 0.001 & 0.001 & 0.001 & 0.005 & 0.000 & 0.000 \\
122 & 0.010 & 0.009 & 0.001 & 0.001 & 0.001 & 0.000 & 0.000 & 0.000 \\
103 & 0.010 & 0.009 & 0.001 & 0.001 & 0.001 & 0.000 & 0.000 & 0.001 \\
80 & 0.009 & 0.007 & 0.016 & 0.000 & 0.000 & 0.000 & 0.000 & 0.000 \\
59 & 0.008 & 0.028 & 0.020 & 0.019 & 0.017 & 0.000 & 0.000 & 0.000 \\
38 & 0.009 & 0.019 & 0.022 & 0.025 & 0.028 & 0.009 & 0.006 & 0.000 \\
17 & 0.030 & 0.027 & 0.040 & 0.045 & 0.051 & 0.058 & 0.058 & 0.068 \\
16 & NA $^{(\text {(b) }}$ & NA & NA & NA & NA & 0.059 & 0.060 & NA \\
\hline
\end{tabular}

(a) 101 inches for gamma scans 10,11, and 12 .

(b) NA-no data taken at this elevation. 
The solids concentration data of Table 2.4 and Table 2.5 were converted to UDS mass via trapezoidal integration with elevation as

$$
\mathrm{m}_{\mathrm{Si}}=\Delta \mathrm{z}_{\mathrm{i}} \mathrm{A}_{\mathrm{T}} \rho_{\mathrm{Bi}} \mathrm{w}_{\mathrm{Si}}
$$

where $\Delta \mathrm{z}_{\mathrm{i}}$ is the difference in elevation for gamma measurement interval $\mathrm{i}$, and $\mathrm{w}_{\mathrm{Si}}$ is the average mass fraction in $\Delta z_{i}$. The mass fraction at 290 inches is assumed to extend to the waste surface (329 inches). The bulk density in $\Delta z_{i}, \rho_{B i}$, is given by

$$
\rho_{\mathrm{Bi}}=\frac{1}{\frac{\mathrm{w}_{\mathrm{Si}}}{\rho_{\mathrm{S}}}+\frac{1-\mathrm{w}_{\mathrm{Si}}}{\rho_{\mathrm{L}}}}
$$

It is assumed that the UDS density is constant with elevation.

The UDS mass in Table 2.6 and Table 2.7 represents the UDS mass from the indicated elevation to the next elevation above. It is again apparent that Approach 1 results in significant solids at elevations the URSILLA and grab samples indicated were solids free. Also included in Table 2.6 and Table 2.7 is the summation of the UDS from the lowest gamma measurement elevation, approximately 17 inches.

Comparing this sum to the estimated total UDS in the tank, 141,565 kg (Section 2.1.1.1), shows that the results from Approach 1 for gamma scan 5 (profile 1 of Figure 2.3), taken immediately post-mixing, are unphysical. Neglecting any solids that are present below 17 inches (concentration may be reasonably expected to be at least that at 17 inches), the summed UDS mass exceeds the total UDS mass by $14 \%$. Thus, it is conclusively shown that Approach 1 over-predicts the UDS suspension.

The mass fraction of UDS below the bottom gamma measurement elevation resulting from Approach 2 was compared to the mass fraction of UDS in the initial sediment and that of grab-sample 1AZ-00-67. This provided a basis for considering whether Approach 2 under-predicts the UDS suspension for gamma cps greater than those directly associated with the grab-sample concentration data.

The average solids concentration, $\mathrm{w}_{\mathrm{SA}}$, below the bottom gamma measurement elevation is given by

$$
\mathrm{w}_{\mathrm{SA}}=\frac{1}{1+\rho_{\mathrm{L}}\left(\frac{\Delta \mathrm{zA}_{\mathrm{T}}}{\Delta \mathrm{m}_{\mathrm{S}}}-\frac{1}{\rho_{\mathrm{S}}}\right)}
$$

where $\Delta \mathrm{z}$ is the lowest gamma measurement elevation, and $\Delta \mathrm{m}_{\mathrm{S}}$, the mass of UDS below the bottom gamma measurement elevation, is the difference in the estimated total $(141,565 \mathrm{~kg})$ and summed UDS mass.

From Section 2.1.1.1, the average solids concentration in the initial sediment was $48 \%$ by mass. It is thus reasonable to expect that, allowing for observed radial variation in the concentration of solids on the tank bottom (Carlson et al. 2001), the maximum UDS concentration in the tank will not significantly 
exceed this value. Equation (2.21) results are provided in Table 2.8, and all results are reasonable with respect to the initial condition.

Table 2.6. UDS Mass, Approach 1

\begin{tabular}{|c|c|c|c|c|c|c|c|c|}
\hline \multirow{2}{*}{$\begin{array}{l}\text { Elevation } \\
\text { (in.) }\end{array}$} & \multicolumn{8}{|c|}{$\mathrm{m}_{\mathrm{Si}}(\mathrm{kg}$ ), Gamma Scan Identification \# (see App. A, 5/31/00 to 6/2/00) } \\
\hline & 5 & 6 & 7 & 8 & 9 & 10 & 11 & 12 \\
\hline 290 & 22074 & 3023 & 5923 & 2146 & 2106 & 1798 & 447 & 873 \\
\hline 269 & 11403 & 1049 & 2437 & 998 & 851 & 491 & 120 & 234 \\
\hline 248 & 10782 & 689 & 1675 & 1193 & 934 & 182 & 86 & 381 \\
\hline 227 & 10429 & 450 & 1595 & 1164 & 1153 & 289 & 85 & 498 \\
\hline 206 & 10811 & 0 & 1485 & 808 & 990 & 437 & 229 & 123 \\
\hline 185 & 10497 & 4149 & 1512 & 1687 & 1001 & 747 & 269 & 0 \\
\hline 164 & 10071 & 8371 & 1592 & 1807 & 1148 & 523 & 136 & 272 \\
\hline 143 & 10452 & 8404 & 1426 & 1100 & 1113 & 2247 & 96 & 272 \\
\hline 122 & 10104 & 8253 & 1148 & 969 & 883 & 2330 & 0 & 0 \\
\hline $103^{(\mathrm{a})}$ & 8687 & 7188 & 979 & 626 & 626 & 178 & 0 & 258 \\
\hline 80 & 10299 & 8173 & 9095 & 336 & 339 & 0 & 0 & 258 \\
\hline 59 & 8286 & 16699 & 17161 & 8849 & 7792 & 0 & 0 & 0 \\
\hline 38 & 8228 & 22780 & 20300 & 20889 & 21452 & 4038 & 2706 & 13 \\
\hline 17 & 18562 & 22453 & 30415 & 34500 & 39100 & 32979 & 31075 & 33288 \\
\hline 16 & $\mathrm{NA}^{(\mathrm{b})}$ & NA & NA & NA & NA & 2661 & 2649 & NA \\
\hline Sum & 160685 & 111681 & 96742 & 77070 & 79487 & 48899 & 37898 & 36469 \\
\hline $\begin{array}{l}\text { (a) } 101 \mathrm{i} \\
\text { (b) } \mathrm{NA}-\end{array}$ & or gam & $\begin{array}{l}\text { ins } 10 \\
\text { s elev? }\end{array}$ & d 12 & & & & & \\
\hline
\end{tabular}

Table 2.7. UDS Mass, Approach 2

\begin{tabular}{|c|c|c|c|c|c|c|c|c|}
\hline \multirow{2}{*}{$\begin{array}{l}\text { Elevation } \\
\text { (in.) }\end{array}$} & \multicolumn{8}{|c|}{$\mathrm{m}_{\mathrm{Si}}(\mathrm{kg})$, Gamma Scan Identification \# (see App. A, 5/31/00 to 6/2/00) } \\
\hline & 5 & 6 & 7 & 8 & 9 & 10 & 11 & 12 \\
\hline 290 & 6293 & 873 & 1708 & 620 & 609 & 520 & 129 & 253 \\
\hline 269 & 3253 & 303 & 703 & 289 & 246 & 142 & 35 & 68 \\
\hline 248 & 3078 & 199 & 484 & 345 & 270 & 53 & 25 & 110 \\
\hline 227 & 2979 & 130 & 461 & 336 & 333 & 84 & 25 & 144 \\
\hline 206 & 3086 & 0 & 429 & 234 & 286 & 127 & 66 & 35 \\
\hline 185 & 2998 & 1195 & 437 & 487 & 289 & 216 & 78 & 0 \\
\hline 164 & 2878 & 2397 & 460 & 522 & 332 & 151 & 39 & 79 \\
\hline 143 & 2985 & 2407 & 412 & 318 & 322 & 649 & 28 & 79 \\
\hline 122 & 2887 & 2364 & 332 & 280 & 255 & 672 & 0 & 0 \\
\hline $103^{(a)}$ & 2483 & 2059 & 283 & 181 & 181 & 52 & 0 & 75 \\
\hline 80 & 2946 & 2344 & 2605 & 97 & 98 & 0 & 0 & 75 \\
\hline 59 & 2373 & 4731 & 4859 & 2533 & 2233 & 0 & 0 & 0 \\
\hline 38 & 2357 & 6404 & 5725 & 5886 & 6041 & 1163 & 781 & 4 \\
\hline 17 & 5246 & 6315 & 8467 & 9556 & 10767 & 9152 & 8644 & 9234 \\
\hline 16 & $\mathrm{NA}^{(\mathrm{b})}$ & NA & NA & NA & NA & 713 & 711 & NA \\
\hline Sum & 45843 & 31721 & 27365 & 21684 & 22263 & 13693 & 10560 & 10155 \\
\hline
\end{tabular}

(a) 101 inches for gamma scans 10,11, and 12 .

(b) NA - no data taken at this elevation. 
Table 2.8. Average Mass Fraction of Solids Below Lowest Gamma Measurement Elevation, Equation (2.21). Approach 1.

\begin{tabular}{cccccccc}
\hline \multicolumn{7}{c}{$\mathrm{W}_{\mathrm{SA}}$, Gamma Scan Identification \# (see App. A, 5/31/00 to $\left.6 / 2 / 00\right)$} \\
\hline 5 & 6 & 7 & 8 & 9 & 10 & 11 & 12 \\
\hline 0.36 & 0.41 & 0.42 & 0.44 & 0.43 & 0.48 & 0.49 & 0.47 \\
\hline
\end{tabular}

However, the average mass-fraction results of Table 2.8 are not in agreement with grab-sample 1AZ-00-67, which indicated a mass fraction of 0.094 at an elevation of 6 inches at the time of gamma scan 11 (Table 2.2). This comparison, in conjunction with an average concentration equivalent to the initial condition with the UDS mass still above 17 inches, Table 2.7 (initial sediment depth approximately 17.5 inches) suggests that while Approach 1 is appropriate for gamma cps in the range associated with the grab-sample data (Table 2.3), it under-predicts for the higher gamma cps. Alternatively, as the solidliquid interface approximation from the gamma scans, taken from the midpoint of the high and low gamma readings, is in good agreement with the URSILLA and grab-sample results (Carlson et al. 2001), a more detailed integration scheme for the UDS below the "steps" in the gamma profiles (e.g., Figure 2.3) may provide more equivalent results. Regardless, the Approach 2 results are reasonable within the understanding of the waste conditions, and the results for gamma scan 5, taken immediately post-mixing, are evaluated for UDS suspension with Approach 2.

The gamma cps for gamma-scan 5 from 38 to 290 inches elevation are within the data range. If the initial UDS inventory was homogenously mixed within the tank, the mass fraction of the total UDS above 38 inches would be 0.88 . Thus, if the mixer pump operations in AZ-101 homogenously suspended the waste, the UDS mass 38 inches and above estimated from gamma scan 5 should also be 0.88 . From Table 2.7, the mass fraction of the total UDS above 38 inches is 0.29 , indicating that only $32 \%$ of the UDS required for homogenous mixing were suspended. This result is similar to the quantitative analyses reported in Carlson et al. (2001).

The effect of the delay in measurement (gamma readings are immediately post-mixer pump operation) can be investigated by considering differences in results of gamma scans 5 and 6, which are separated in time equivalent to gamma scan 5 and the mixer pump operation. However, the gamma scans are conducted from the waste surface to the bottom, and gamma scan 5 (profile 1 of Figure 2.3) shows constant count with depth, indicating that settling during gamma scan 5 was not significant. (a) Further, it is reasonable to expect some period of continued significant fluid motion upon cessation of the mixer pump operation. Thus, investigating the delay effect by comparing gamma scans 5 and 6 is expected to over-estimate the potential impact.

The gamma cps for gamma-scan 6 from 80 to 290 inches elevation are within the data range. Homogenous mixing above 80 inches would result in 0.76 of the initial UDS inventory being suspended therein. The mass fractions of the total UDS above 80 inches for gamma scans 5 and 6 are 0.25 and 0.10 , respectively. Therefore the maximum effect of the measurement delay would suggest that $82 \%$ of the UDS required for homogenous mixing were suspended.

(a) The radionuclides expected to be indicated by the reported gamma cps include ${ }^{152} \mathrm{Eu}$ and ${ }^{154} \mathrm{Eu}$ (Carlson et al. 2001). The concentration $\left(\mu \mathrm{Ci} / \mathrm{g}\right.$ ) of ${ }^{154} \mathrm{Eu}$ for the centrifuged solids of grab-samples $1 \mathrm{AZ}-00-35,36$, and 38 (the only samples with this analysis) is relatively constant (Bell 2001). 
The approximate 3.5-hour difference in cessation of mixer pumps 1 and 2 operations potentially influenced the radial distribution of the solids. There is evidence of radial non-homogeneity of UDS on the tank bottom (Carlson et al. 2001). The rotational operation of the mixer pumps may also potentially have influenced the radial distribution of the solids. However, off-bottom radial uniformity is indicated by the very good agreement for the solid-liquid interface from radially distributed instrumentation in five different risers, Section 2.3.1.

Although there are uncertainties in the data (e.g., see discussion on the mass fraction of UDS in the grab samples, Section 2.3.2.1) and the functionality developed from that data (the effect of the fit is expected to be minimized by application within the data region), these uncertainties are not expected to be substantial enough to significantly alter the difference in homogeneity as evaluated. Measurement delays from mixer pump operation and potential radial variation are also not expected to significantly impact the homogeneity difference. 



\subsection{AY-102 Waste Properties and Tank Configuration}

The waste stored in AY-102 consists of a deep liquid layer overlaying a settled solids layer. The total waste depth in AY-102 is approximately 343 inches (TWINS ${ }^{(a)}$ ). Best-estimate values for current AY-102 waste properties are provided in Section 3.1.1. As with the AZ-101 waste properties, Section 2.1.1, significant digits are not considered, and all values are best-estimate approximations. The tank configuration is summarized in Section 3.1.2.

\subsubsection{AY-102 Liquid and Undissolved Solids}

The liquid density in AY-102 is approximately $1.17 \mathrm{~g} / \mathrm{mL}(\mathrm{Hu} 2007)$. A representative liquid temperature is approximately $113^{\circ} \mathrm{F}$ (Hu and Barker 2003), and the dynamic viscosity of AY-102 liquid at that temperature is approximately $3 \mathrm{cP}$ (TWINS data from Attachment B, Warrant 2001; see Onishi and Wells 2004).

The sediment density is approximately $1.55 \mathrm{~g} / \mathrm{mL}$ (Hu 2007), and the UDS have a bulk density of $2.5 \mathrm{~g} / \mathrm{mL}$ (Onishi and Wells 2004). With Equations (2.1) and (2.2), the UDS content in the sediment can be estimated at $29 \%$ by volume, $46 \%$ by mass.

The sediment layer is approximately 64 inches thick (Hu 2007). From Equation (2.3), the UDS mass in the tank is $476,571 \mathrm{~kg}$. The liquid mass is $3,823,922 \mathrm{~kg}$.

\subsubsection{AY-102 UDS Particulate Characterization}

Synonymously with AZ-101, Section 2.1.1.2, the UDS particulate in AY-102 is characterized by a PSDD as per the Case 3 approach of Wells et al. (2007). The presented PSDD is a representation of the AY-102 UDS particulate, and the discrepancy of the UDS density in Section 3.1.1, 2.5 g/mL, and the volume-weighted average from Table $3.1,3.63 \mathrm{~g} / \mathrm{mL}$, is acknowledged.

The AY-102 "minimal disturbance" particle-size distribution was combined with the insoluble solidphase compounds, volume fractions thereof, and crystal densities (Wells et al. 2007, Table A.3 and Section 3.2). The resulting PSDD is provided in Table 3.1.

The settling velocity of the AY-102 PSDD was computed via Equations (2.4) and (2.5), and the cumulative volume-based probability is presented in Figure 3.1. The $50^{\text {th }}$ (median) and $95^{\text {th }}$ percentiles by volume of settling velocity are approximately $4.6 \mathrm{E}-6$ and $8.8 \mathrm{E}-4 \mathrm{~m} / \mathrm{s}$, respectively.

The estimated in situ bulk UDS settling velocity in AY-102 during retrieval of C-106 (approximately $85 \%$ of the sediment by volume in AY-102 is from C-106), inferred from the sediment level growth and liquid depth, ranges from $6 \mathrm{E}-6$ to $5 \mathrm{E}-5 \mathrm{~m} / \mathrm{s}$, depending on the retrieval batch (Cuta et al. 2000). These in situ settling rates correspond approximately to the $55^{\text {th }}$ to $85^{\text {th }}$ percentile of the PSDD, Figure 3.1.

However, the volume-weighted average settling velocity, Equation (2.6), is $3.9 \mathrm{E}-4 \mathrm{~m} / \mathrm{s}$, approximately the $94^{\text {th }}$ percentile of the PSDD. Thus, the volume-weighted average settling velocity exceeds the in situ estimates.

(a) TWINS: Tank Waste Information System database. http://twins.pnl.gov/twins3/twins.htm 
However, the volume-weighted average comparison may be reasonable. This is similar to the AZ-101 comparison, Section 2.1.1.2, in which the percentile results of the AY-102 settling velocity may imply that the measured particle sizes are biased low. It is again emphasized that, as the PSDDs are intended to be representative and are developed synonymously, the AZ-101 and AY-102 waste characteristics were compared with the PSDDs as presented.

\subsubsection{AY-102 Tank Configuration}

Tank AY-102 is essentially equivalent to AZ-101, Section 2.12. It is a 37.5 -ft-radius $1,406,800$ gallon DST with a maximum operating capacity of 1,160,00 gallons (Barker 2003). AY-102 contains ALCs in the same configuration as AZ-101. 
Table 3.1. AY-102 PSDD

\begin{tabular}{|c|c|c|c|c|c|c|c|c|c|c|c|}
\hline \multirow[b]{4}{*}{ Particle Size $(\mu \mathrm{m})$} & \multicolumn{11}{|c|}{ Solid Phase Compounds and Density $(\mathrm{g} / \mathrm{mL})$} \\
\hline & $\mathrm{Fe}_{2} \mathrm{O}_{3}$ & $\mathrm{Al}(\mathrm{OH})_{3}$ & $\mathrm{Ca}_{5} \mathrm{OH}\left(\mathrm{PO}_{4}\right)_{3}$ & $\mathrm{MnO}_{2}$ & $\mathrm{Ni}(\mathrm{OH})_{2}$ & $\mathrm{Na}_{2} \mathrm{U}_{2} \mathrm{O}_{7}$ & $\mathrm{LaPO}_{4} \cdot 2 \mathrm{H}_{2} \mathrm{O}$ & $\mathrm{Bi}_{2} \mathrm{O}_{3}$ & $\mathrm{Ag}_{2} \mathrm{CO}_{3}$ & $\mathrm{ZrO}_{2}$ & $\mathrm{PuO}_{2}$ \\
\hline & 5.24 & 2.42 & 3.14 & 5.026 & 4.1 & & 6.51 & & & 5.68 & 11.43 \\
\hline & \multicolumn{11}{|c|}{ Solid Volume Fraction } \\
\hline 0.22 & $3.4 \mathrm{E}-05$ & $5.3 \mathrm{E}-05$ & $5.3 \mathrm{E}-06$ & $5.2 \mathrm{E}-06$ & $1.2 \mathrm{E}-06$ & $1.0 \mathrm{E}-06$ & $4.8 \mathrm{E}-07$ & $2.4 \mathrm{E}-08$ & $8.6 \mathrm{E}-09$ & $6.5 \mathrm{E}-09$ & $3.9 \mathrm{E}-09$ \\
\hline 0.28 & 4.6E- 04 & 7.1E-04 & 7.2E- 05 & $7.0 \mathrm{E}-05$ & $1.6 \mathrm{E}-05$ & $1.4 \mathrm{E}-05$ & $6.5 \mathrm{E}-06$ & $3.3 \mathrm{E}-07$ & $1.2 \mathrm{E}-07$ & $8.8 \mathrm{E}-08$ & $5.3 \mathrm{E}-08$ \\
\hline 0.36 & $6.5 \mathrm{E}-04$ & $1.0 \mathrm{E}-03$ & $1.0 \mathrm{E}-04$ & $1.0 \mathrm{E}-04$ & $2.2 \mathrm{E}-05$ & $2.0 \mathrm{E}-05$ & $9.2 \mathrm{E}-06$ & $4.7 \mathrm{E}-07$ & $1.7 \mathrm{E}-07$ & $1.2 \mathrm{E}-07$ & $7.5 \mathrm{E}-08$ \\
\hline 0.46 & $6.6 \mathrm{E}-04$ & $1.0 \mathrm{E}-03$ & $1.0 \mathrm{E}-04$ & $1.0 \mathrm{E}-04$ & 2.3E-05 & $2.0 \mathrm{E}-05$ & $9.3 \mathrm{E}-06$ & 4.7E-07 & $1.7 \mathrm{E}-07$ & $1.3 \mathrm{E}-07$ & 7.6E-08 \\
\hline 0.6 & $9.5 \mathrm{E}-04$ & $1.5 \mathrm{E}-03$ & $1.5 \mathrm{E}-04$ & $1.5 \mathrm{E}-04$ & 3.3E-05 & $2.8 \mathrm{E}-05$ & $1.3 \mathrm{E}-05$ & $6.8 \mathrm{E}-07$ & $2.4 \mathrm{E}-07$ & $1.8 \mathrm{E}-07$ & $1.1 \mathrm{E}-07$ \\
\hline 0.77 & $5.6 \mathrm{E}-03$ & $8.7 \mathrm{E}-03$ & $8.7 \mathrm{E}-04$ & $8.6 \mathrm{E}-04$ & $1.9 \mathrm{E}-04$ & $1.7 \mathrm{E}-04$ & $7.9 \mathrm{E}-05$ & $4.0 \mathrm{E}-06$ & $1.4 \mathrm{E}-06$ & $1.1 \mathrm{E}-06$ & $6.5 \mathrm{E}-07$ \\
\hline 1 & $2.3 \mathrm{E}-02$ & $3.5 \mathrm{E}-02$ & $3.5 \mathrm{E}-03$ & $3.4 \mathrm{E}-03$ & 7.7E-04 & $6.7 \mathrm{E}-04$ & $3.2 \mathrm{E}-04$ & $1.6 \mathrm{E}-05$ & $5.7 \mathrm{E}-06$ & 4.3E-06 & $2.6 \mathrm{E}-06$ \\
\hline 1.29 & $3.7 \mathrm{E}-02$ & $5.7 \mathrm{E}-02$ & $5.7 \mathrm{E}-03$ & $5.6 \mathrm{E}-03$ & $1.3 \mathrm{E}-03$ & $1.1 \mathrm{E}-03$ & $5.2 \mathrm{E}-04$ & $2.6 \mathrm{E}-05$ & $9.3 \mathrm{E}-06$ & $7.0 \mathrm{E}-06$ & 4.2E-06 \\
\hline 1.67 & $3.4 \mathrm{E}-02$ & $5.2 \mathrm{E}-02$ & $5.2 \mathrm{E}-03$ & $5.1 \mathrm{E}-03$ & $1.2 \mathrm{E}-03$ & $1.0 \mathrm{E}-03$ & 4.7E-04 & $2.4 \mathrm{E}-05$ & $8.5 \mathrm{E}-06$ & $6.4 \mathrm{E}-06$ & $3.9 \mathrm{E}-06$ \\
\hline 2.15 & $3.0 \mathrm{E}-02$ & $4.7 \mathrm{E}-02$ & $4.8 \mathrm{E}-03$ & 4.6E- 03 & $1.0 \mathrm{E}-03$ & $9.1 \mathrm{E}-04$ & $4.3 \mathrm{E}-04$ & $2.2 \mathrm{E}-05$ & 7.7E-06 & $5.8 \mathrm{E}-06$ & $3.5 \mathrm{E}-06$ \\
\hline 2.78 & $3.1 \mathrm{E}-02$ & $4.9 \mathrm{E}-02$ & $4.9 \mathrm{E}-03$ & $4.8 \mathrm{E}-03$ & $1.1 \mathrm{E}-03$ & $9.4 \mathrm{E}-04$ & 4.4E-04 & $2.3 \mathrm{E}-05$ & $7.9 \mathrm{E}-06$ & $6.0 \mathrm{E}-06$ & 3.6E-06 \\
\hline 3.59 & $2.8 \mathrm{E}-02$ & $4.4 \mathrm{E}-02$ & $4.4 \mathrm{E}-03$ & 4.3E-03 & $9.6 \mathrm{E}-04$ & $8.4 \mathrm{E}-04$ & $4.0 \mathrm{E}-04$ & $2.0 \mathrm{E}-05$ & 7.1E-06 & $5.4 \mathrm{E}-06$ & $3.2 \mathrm{E}-06$ \\
\hline 4.64 & $2.7 \mathrm{E}-02$ & $4.2 \mathrm{E}-02$ & $4.3 \mathrm{E}-03$ & $4.2 \mathrm{E}-03$ & $9.4 \mathrm{E}-04$ & $8.2 \mathrm{E}-04$ & $3.8 \mathrm{E}-04$ & $2.0 \mathrm{E}-05$ & $6.9 \mathrm{E}-06$ & $5.2 \mathrm{E}-06$ & $3.1 \mathrm{E}-06$ \\
\hline 5.99 & $2.5 \mathrm{E}-02$ & $3.8 \mathrm{E}-02$ & $3.8 \mathrm{E}-03$ & $3.8 \mathrm{E}-03$ & $8.5 \mathrm{E}-04$ & 7.4E-04 & $3.5 \mathrm{E}-04$ & $1.8 \mathrm{E}-05$ & $6.2 \mathrm{E}-06$ & 4.7E-06 & $2.8 \mathrm{E}-06$ \\
\hline 7.74 & $2.0 \mathrm{E}-02$ & $3.2 \mathrm{E}-02$ & $3.2 \mathrm{E}-03$ & $3.1 \mathrm{E}-03$ & 7.0E-04 & $6.1 \mathrm{E}-04$ & $2.9 \mathrm{E}-04$ & $1.5 \mathrm{E}-05$ & $5.2 \mathrm{E}-06$ & $3.9 \mathrm{E}-06$ & $2.4 \mathrm{E}-06$ \\
\hline 10 & $1.7 \mathrm{E}-02$ & $2.6 \mathrm{E}-02$ & $2.6 \mathrm{E}-03$ & $2.6 \mathrm{E}-03$ & $5.7 \mathrm{E}-04$ & $5.0 \mathrm{E}-04$ & $2.4 \mathrm{E}-04$ & $1.2 \mathrm{E}-05$ & $4.2 \mathrm{E}-06$ & $3.2 \mathrm{E}-06$ & $1.9 \mathrm{E}-06$ \\
\hline 12.92 & $1.6 \mathrm{E}-02$ & $2.5 \mathrm{E}-02$ & $2.5 \mathrm{E}-03$ & $2.5 \mathrm{E}-03$ & $5.5 \mathrm{E}-04$ & $4.8 \mathrm{E}-04$ & $2.3 \mathrm{E}-04$ & $1.2 \mathrm{E}-05$ & $4.1 \mathrm{E}-06$ & $3.1 \mathrm{E}-06$ & $1.9 \mathrm{E}-06$ \\
\hline 16.68 & $1.5 \mathrm{E}-02$ & $2.3 \mathrm{E}-02$ & $2.3 \mathrm{E}-03$ & $2.3 \mathrm{E}-03$ & $5.2 \mathrm{E}-04$ & $4.5 \mathrm{E}-04$ & $2.1 \mathrm{E}-04$ & $1.1 \mathrm{E}-05$ & $3.8 \mathrm{E}-06$ & $2.9 \mathrm{E}-06$ & $1.7 \mathrm{E}-06$ \\
\hline 21.54 & $6.4 \mathrm{E}-03$ & $1.0 \mathrm{E}-02$ & $1.0 \mathrm{E}-03$ & $9.8 \mathrm{E}-04$ & $2.2 \mathrm{E}-04$ & $1.9 \mathrm{E}-04$ & $9.1 \mathrm{E}-05$ & 4.6E-06 & $1.6 \mathrm{E}-06$ & $1.2 \mathrm{E}-06$ & 7.4E-07 \\
\hline 27.83 & $2.0 \mathrm{E}-03$ & $3.1 \mathrm{E}-03$ & $3.1 \mathrm{E}-04$ & $3.0 \mathrm{E}-04$ & $6.8 \mathrm{E}-05$ & $5.9 \mathrm{E}-05$ & $2.8 \mathrm{E}-05$ & $1.4 \mathrm{E}-06$ & $5.0 \mathrm{E}-07$ & $3.8 \mathrm{E}-07$ & $2.3 \mathrm{E}-07$ \\
\hline 35.94 & $1.1 \mathrm{E}-03$ & $1.8 \mathrm{E}-03$ & $1.8 \mathrm{E}-04$ & $1.7 \mathrm{E}-04$ & $3.9 \mathrm{E}-05$ & $3.4 \mathrm{E}-05$ & $1.6 \mathrm{E}-05$ & $8.1 \mathrm{E}-07$ & $2.9 \mathrm{E}-07$ & $2.2 \mathrm{E}-07$ & $1.3 \mathrm{E}-07$ \\
\hline 46.42 & $1.4 \mathrm{E}-03$ & $2.2 \mathrm{E}-03$ & $2.3 \mathrm{E}-04$ & $2.2 \mathrm{E}-04$ & $5.0 \mathrm{E}-05$ & $4.3 \mathrm{E}-05$ & $2.0 \mathrm{E}-05$ & $1.0 \mathrm{E}-06$ & 3.6E-07 & $2.8 \mathrm{E}-07$ & $1.7 \mathrm{E}-07$ \\
\hline 59.95 & $1.7 \mathrm{E}-03$ & $2.7 \mathrm{E}-03$ & $2.7 \mathrm{E}-04$ & 2.6E-04 & $5.9 \mathrm{E}-05$ & $5.2 \mathrm{E}-05$ & $2.4 \mathrm{E}-05$ & $1.2 \mathrm{E}-06$ & 4.4E-07 & $3.3 \mathrm{E}-07$ & $2.0 \mathrm{E}-07$ \\
\hline 77.43 & $2.3 \mathrm{E}-03$ & $3.6 \mathrm{E}-03$ & 3.6E-04 & $3.6 \mathrm{E}-04$ & $8.0 \mathrm{E}-05$ & $7.0 \mathrm{E}-05$ & $3.3 \mathrm{E}-05$ & $1.7 \mathrm{E}-06$ & $5.9 \mathrm{E}-07$ & 4.4E-07 & 2.7E-07 \\
\hline 100 & $3.2 \mathrm{E}-03$ & $5.0 \mathrm{E}-03$ & $5.0 \mathrm{E}-04$ & $4.9 \mathrm{E}-04$ & 1.1E-04 & $9.5 \mathrm{E}-05$ & $4.5 \mathrm{E}-05$ & $2.3 \mathrm{E}-06$ & 8.0E-07 & $6.1 \mathrm{E}-07$ & 3.7E-07 \\
\hline 129.15 & $4.1 \mathrm{E}-03$ & $6.4 \mathrm{E}-03$ & $6.4 \mathrm{E}-04$ & $6.3 \mathrm{E}-04$ & $1.4 \mathrm{E}-04$ & $1.2 \mathrm{E}-04$ & $5.8 \mathrm{E}-05$ & $3.0 \mathrm{E}-06$ & $1.0 \mathrm{E}-06$ & $7.9 \mathrm{E}-07$ & $4.8 \mathrm{E}-07$ \\
\hline 166.81 & $3.1 \mathrm{E}-03$ & $4.8 \mathrm{E}-03$ & $4.8 \mathrm{E}-04$ & 4.7E-04 & $1.1 \mathrm{E}-04$ & $9.2 \mathrm{E}-05$ & $4.3 \mathrm{E}-05$ & $2.2 \mathrm{E}-06$ & 7.8E-07 & $5.9 \mathrm{E}-07$ & $3.5 \mathrm{E}-07$ \\
\hline 215.44 & $2.6 \mathrm{E}-03$ & $4.1 \mathrm{E}-03$ & $4.1 \mathrm{E}-04$ & $4.0 \mathrm{E}-04$ & $8.9 \mathrm{E}-05$ & $7.8 \mathrm{E}-05$ & $3.7 \mathrm{E}-05$ & $1.9 \mathrm{E}-06$ & $6.6 \mathrm{E}-07$ & $5.0 \mathrm{E}-07$ & $3.0 \mathrm{E}-07$ \\
\hline 278.26 & $2.1 \mathrm{E}-04$ & 3.3E-04 & $3.3 \mathrm{E}-05$ & $3.2 \mathrm{E}-05$ & 7.3E-06 & $6.4 \mathrm{E}-06$ & $3.0 \mathrm{E}-06$ & $1.5 \mathrm{E}-07$ & $5.4 \mathrm{E}-08$ & 4.1E- 08 & 2.4E- 08 \\
\hline Total Solid-Phase Volume Fraction & 0.34 & 0.53 & 0.053 & 0.052 & 0.012 & 0.010 & 0.005 & 0.0002 & 0.00009 & 0.00006 & 0.00004 \\
\hline
\end{tabular}




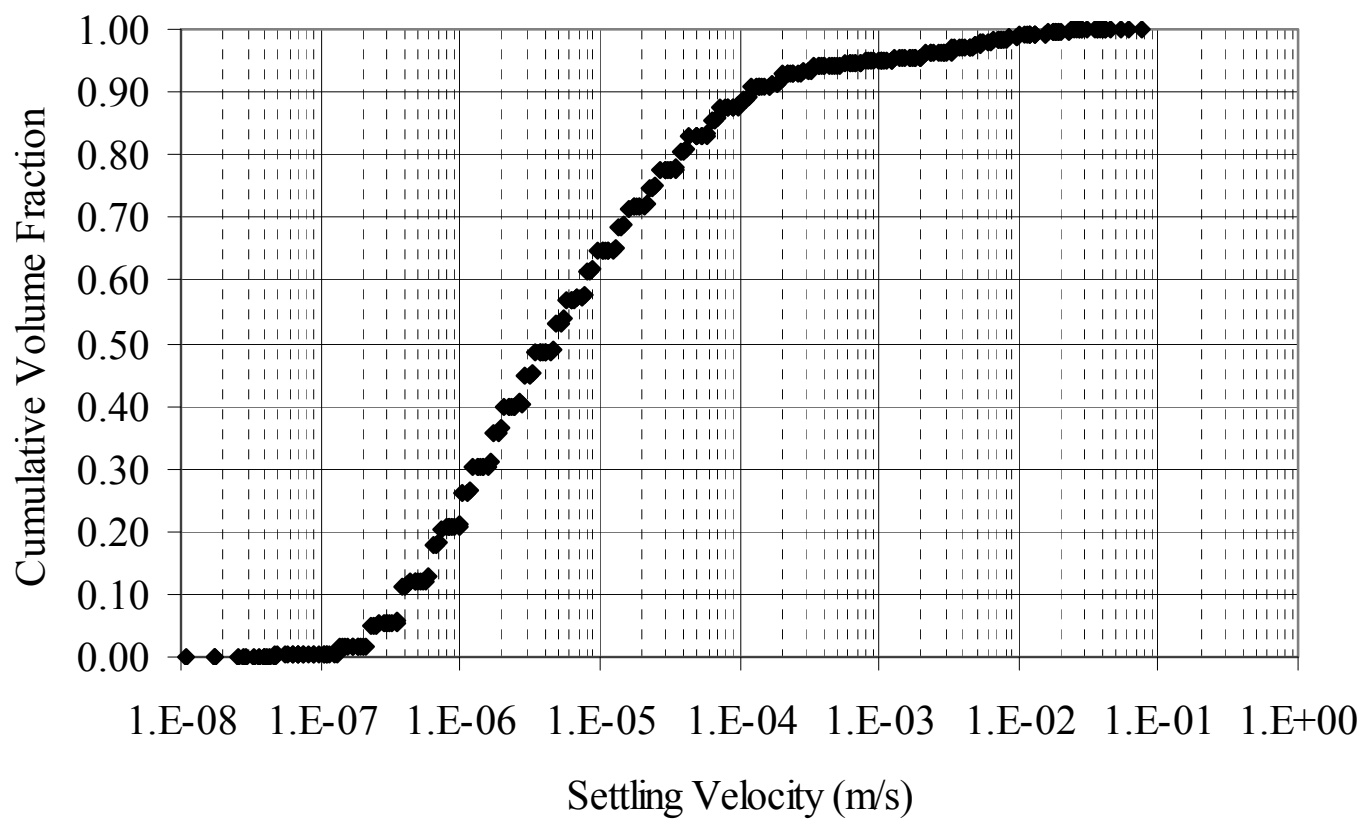

Figure 3.1. Cumulative UDS Volume Fraction as Function of Settling Velocity for AY-102 


\subsection{Conclusions}

The suspension of solids in Hanford DST AZ-101 due to operation of the baseline mixing system has been evaluated, Section 2.3. It is concluded that the mixing in AZ-101 resulted in suspension of $32 \%$ of the particulate required for homogenous suspension.

AY-102 is the WTP commissioning feed tank, and the solid suspension therein is considered via the solid suspension performance of the baseline feed delivery mixer pumps in AZ-101. The AZ-101 and AY-102 waste properties and tank configurations were compared, and the implications for solids suspension in AY-102 are discussed in Section 4.1. Estimates for the Hanford waste in general for DST feed staging tanks are made in Section 4.2. Recommendations are provided in Section 4.3 for improving the understanding of solids suspension during mixer pump operation.

\subsection{Solid Suspension AY-102}

The tank configurations of AZ-101 and AY-102 are equivalent, Sections 2.1.2 and 3.1.2. Thus, any differences in the suspension of solids via equivalent operation of the baseline mixing system are due to differences in the waste properties.

AZ-101 and AY-102 waste properties are reported in Sections 2.1.1 and 3.1.1 respectively. The 4\% difference in fill heights in AZ-101 and AY-102 will not influence mixing performance. The UDS particulate was compared with the volume-weighted average settling velocity. The volume-weighted average settling velocity in AZ-101 (4.3E-5 m/s, Section 2.1.1.2) is approximately $10 \%$ of that in AY-102 (3.9E-4 $\mathrm{m} / \mathrm{s}$, Section 3.1.1.1). It is therefore expected that the quantity of solids suspension in AY-102 for equivalent conditions would be less than that of AZ-101. The anomaly of the in situ settling velocity and the PSDD results presented in Sections 2.1.1.2 and 3.1.1.1 may exacerbate the settling velocity difference.

The mixing analysis of AY-102, Onishi and Wells (2004), was focused on the capability of the baseline mixer pumps to mobilize the sediment. As such, the waste properties selected focused on those pertinent to mobilization (i.e., sediment shear strength), and representative values were selected for the remaining properties. The particle-size distribution is taken from the same reference as that of the current analysis (Bechtold 2002), but the outlier particle-size distribution of Bechtold (2002) was excluded from Onishi and Wells (2004). The $99^{\text {th }}$ percentile particle size in the current analysis is thus approximately $167 \mu \mathrm{m}$ compared to $17 \mu \mathrm{m}$ in Onishi and Wells. In addition, the solids particulate density in Onishi and Wells (2004) was set at $2.5 \mathrm{~g} / \mathrm{mL}$, while in the current analysis, the density ranges from 2.42 to $11.43 \mathrm{~g} / \mathrm{mL}$ as a function of the fraction of the individual solid phase compounds. As a result, the volume-weighted average settling velocity of Onishi and Wells (2004) is less than 4\% that of the current analysis. Once solid particulate was mobilized, it was suspended, and near homogenous suspension was indicated for the sediment that was mobilized.

AY-102 contains approximately 3.4 times as much UDS by mass as AZ-101. Therefore, for the same operating conditions, suspension in AY-102 would be reduced. However, increased solids loading may reduce the particulate settling velocity, so conflicting phenomena with regards to particulate suspension exist. Other complicating phenomenon such as pump performance with increased solids loading may impact mixing performance as well. 
The ratio of the hindered particulate settling velocity to free particulate settling velocity is significantly impacted once the solid concentration exceeds approximately $10 \%$ by volume (Govier and Aziz 1987). Fully homogenous conditions in AY-102 would result in a solids concentration by volume of approximately $5 \%$.

The hindered settling velocity can be expressed by

$$
\mathrm{U}_{\mathrm{H}}=\mathrm{U}_{\mathrm{T}}\left(1-\frac{\phi}{\phi_{\max }}\right)^{4.5}
$$

where $U_{T}$ is the free settling velocity (see Equation [2.4]), and $\phi$ and $\phi_{\max }$ are the local and settled volume fractions, respectively (Wells et al. 2008). Holding the kinematic viscosity of Equation (2.4) constant at the liquid value, the homogenous concentration of 5\% reduces the AY-102 particulate volume-weighted average settling velocity such that AZ-101 is $25 \%$ that of AY-102. A solids concentration of approximately $11 \%$ by volume is required to reduce the volume-weighted average settling velocity of the AY-102 particulate to that of AZ-101.

Comparing the AY-102 and AZ-101 waste properties suggests that the non-homogenous mixing results of AZ-101 imply that AY-102 will not be homogenously mixed by the baseline mixing system. It is likely that less than $32 \%$ of the particulate required for homogenous suspension would be achieved.

\subsection{Solids Suspension for Hanford Waste}

Solids-suspension estimates for the Hanford waste in general in any DST feed staging tank with the baseline mixing system were considered. All Hanford DSTs are essentially equivalent in tank configuration with the exception of the ALCs (Barker 2003). The effect of the ALCs on sediment mobilization and suspension has not been quantified. However, in a computational fluid dynamics analysis of pump jet mixing in AZ-102, Onishi et al. (2000), it was concluded that the ALCs did not have a significant impact on the sediment erosion.

If the influence of the ALCs is assumed to be minimal, the suspension of solids in any feed tank is a function of the waste properties. So long as the solid-liquid interface during mixing is, as in AZ-101, the waste surface, solids suspension will not be a function of the fill height. If it is further assumed that the liquid properties are rendered relatively constant by the dilution process required to prepare the waste for the WTP, then the suspension of the solids will be dependent solely on the particulate properties.

The Case 3 PSDD of Wells et al. (2007) represents the Hanford insoluble solids as a whole, and, as evidenced by the variation to the PSDDs of AZ-101 and AY-102, Sections 2.1.1 and 3.1.1, variability is expected within the feed tanks. The Case 3 PSDD is used for this general qualitative discussion.

The cumulative volume-based probability of the settling velocity of the Case 3 PSDD is presented in Figure 4.1. The $50^{\text {th }}$ (median) and $95^{\text {th }}$ percentiles by volume of settling velocity are approximately $4.6 \mathrm{E}-5$ and $3.8 \mathrm{E}-3 \mathrm{~m} / \mathrm{s}$, respectively. The volume-weighted average settling velocity is $1.4 \mathrm{E}-3 \mathrm{~m} / \mathrm{s}$, approximately 30 and 4 times those of AZ-101 and AY-102, respectively. 


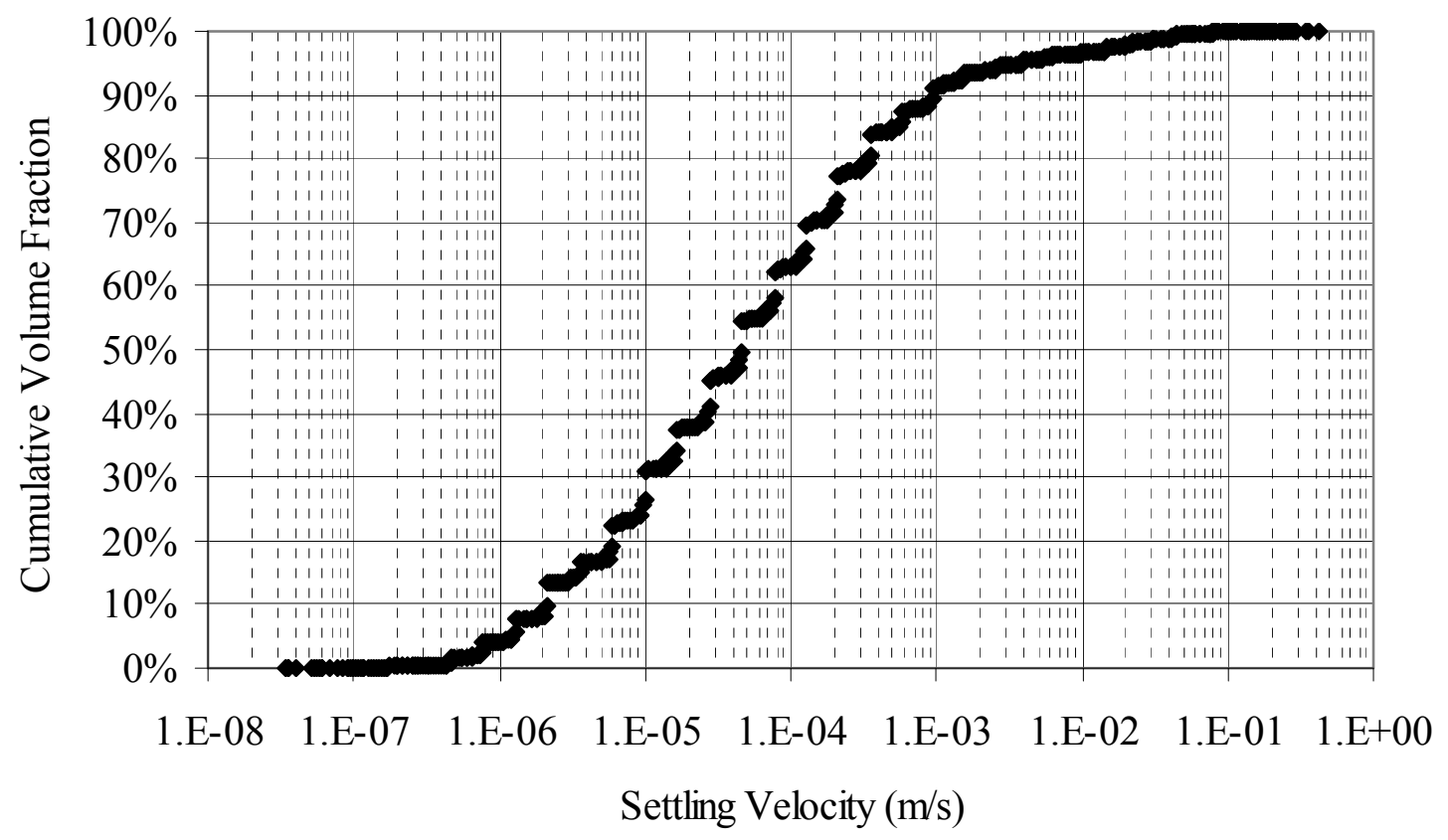

Figure 4.1. Cumulative UDS Volume Fraction as Function of Settling Velocity for Hanford Insoluble Solids, Case 3 PSDD, Wells et al. (2007)

The sediment depths in the DST feed staging tanks may be up to 200 inches. The solid volume fraction in AZ-101, 0.32, can be shown to bound the current Hanford sludge (i.e., insoluble solid) sediment, with typical values at 0.2 to 0.3 . Thus, with a sediment 200 inches deep, the solids loading in a DST feed staging tank may exceed that of AZ-101 by approximately 10 times. Fully homogenous conditions in a feed staging tank with 200 inches of sediment at $30 \%$ solids by volume and a maximum fill height of 420 inches would result in a solids concentration by volume of approximately $14 \%$. This solids concentration would reduce the volume-weighted average settling velocity of the Hanford insoluble particulate to approximately 2 times that of AZ-101.

The qualitative comparison implies that the baseline mixing system will face significant challenges in DST feed staging tanks with regard to homogenous suspension of the Hanford insoluble solids.

\subsection{Recommendations}

Recommendations of subject areas that should be focused on, either in the application of existing instrumentation or for new instrumentation, to reduce uncertainties in the homogeneity of mixing include:

- Develop calibrated concentration data for the concentration measurement device over the expected range of concentrations.

- Deploy the concentration measurement device during active mixing.

- Deploy the concentration measurement device over the waste depth. Tank-bottom information is critical. 
- Deploy the concentration measurement device at different radial locations.

- Develop concurrent concentration data and sample analysis of in situ conditions.

- Operational changes such as waste transfer will affect mixing, and the effects must be evaluated.

- Select mixing demonstration vessels that have waste properties that span or bound solids properties and concentrations.

o Waste properties must be well characterized.

- Waste chemistry may significantly impact particulate response to shear and subsequent settling rates.

o Pump operation parameters must be monitored, controlled, and exercised.

o The relationship of the solid-liquid interface to the liquid surface level must be similar for different vessels.

The development of a data analysis plan to achieve the desired outcomes before testing is critical. The "Lessons Learned" provided in Carlson et al. (2001) should be reviewed and implemented to the extent possible as part of this process. 


\subsection{References}

Barker SA. 2003. Determination of Hanford Waste Tank Volumes. RPP-13019, Rev. 0, CH2M HILL Hanford Group, Inc., Richland, WA.

Bechtold DB, WS Callaway, GA Cooke, JB Duncan, DL Herting, JR Jewett, JC Person, and JM TIngey. 2002. Particle Property Analyses of High-Level Waste Tank Sludges. HNF-8862 Rev. 0, Fluor Hanford, Richland, WA.

Bell KE. 2000. Tank 241-AZ-101 Grab Samples Mixer Pump Test Event 6, Analytical Results for the Final Report. HNF-6052, Rev 0, Fluor Hanford, Richland, WA.

Bell KE. 2001. Tank 241-AZ-101 Grab Samples From Mixer Pump Test Events 5, 7, 8, and 9 Analytical Results for the Final Results for the Report. HNF-6062, Rev 0, Fluor Hanford, Richland, WA.

Callaway WS. 2000. Results of Retrieval Testing of Sludge from Tank 241-AZ-101. HNF-7078, Rev. 1, Fluor Hanford, Richland, WA.

Camenen B. 2008. "Simple and General Formula for the Settling Velocity of Particles." Journal of Hydraulic Engineering - ASCE 133(2):229-233.

Carlson AB, PJ Certa, TM Hohl, JR Bellomy III, TW Crawford, DC Hedengren, AM Templeton, HS Fisher, SJ Greenwood, DG Douglas, and WJ Ulbright Jr. 2001. Test Report, 241-AZ-101 Mixer Pump Test. RPP-6548, Rev. 1, Numatec Hanford Corporation, Richland, WA.

Cuta JM, KG Carothers, DW Damschen, WL Kuhn, JA Lechelt, K Sathyanarayana, and LA Stauffer. 2000. Review of Waste Retrieval Sluicing System Operations and Data for Tanks 241-C-106 and 241-AY-102. PNNL-13319, Pacific Northwest National Laboratory, Richland, WA.

Enderlin CW, G Terrones, CJ Bates, BK Hatchell, and B Adkins. 2003. Recommendations for Advances Design Mixer Pump Operation in Savannah River Site Tank 18F. PNNL-14443, Pacific Northwest National Laboratory, Richland, WA.

Govier GW, and K Aziz. 1987. The Flow of Complex Mixtures in Pipes. ISBN 0-88275-547-1, Robert E Krieger Publishing Company, Inc. Malabar, FL.

Hall MN. 2008. ICD 19 - Interface Control Document for Waste Feed. 24590-WTP-ICD-MG-01-019, Rev 4. River Protection Project, Waste Treatment Plant, Richland, WA.

Hu TA. 2007. Methodology and Calculations for the Assignment of Waste Groups for the Large Underground Waste Storage Tanks at the Hanford Site. RPP-10006, Rev. 6., CH2M HILL Hanford Group, Inc., Richland, WA. 
Hu TA, and SA Barker. 2003. Steady-State Flammable Gas Release Rate Calculation and Lower Flammability Level Evaluation for Hanford Tank Waste. RPP-5926, Rev. 2A, CH2M HILL Hanford Group, Inc., Richland, WA.

Knoll GF. 2000. Radiation Detection and Measurement. ISBN 0-471-07338-5, John Wiley and Sons, Inc., Hoboken, NJ.

Onishi Y, and BE Wells. 2004. Feasibility Study on Using Two Mixer Pumps for Tank 241-AY-102 Waste Mixing. PNNL-14763, Pacific Northwest National Laboratory, Richland, WA.

Onishi Y, KP Recknagle, and BE Wells. 2000. Pump Jet Mixing and Pipeline Transfer Assessment for High-Activity Radioactive Wastes in Hanford Tank 241-AZ-102. PNNL-13275, Pacific Northwest National Laboratory, Richland, WA.

Onishi Y, BE Wells, SA Hartley, and SK Cooley. 2002. Pipeline Cross-Site Transfer Assessment for Tank 241-SY-101. PNNL-13650, Pacific Northwest National Laboratory, Richland, WA.

Stewart CW, MS Fountain, JL Huckaby, LA Mahoney, PA Meyer, and BE Wells. 2005. Effects of Globally Waste-Disturbing Activities on Gas Generation, Retention, and Release in Hanford Waste Tanks. PNNL-13781, Rev. 3, Pacific Northwest National Laboratory, Richland, WA.

Warrant RW. 2001. Results of Retrieval Testing of Sludge from Tank 241-AY-102. RPP-8909, Rev 0, Fluor Hanford, Richland, WA.

Wells BE, MA Knight, EC Buck, SK Cooley, RC Daniel, LA Mahoney, PA Meyer, AP Poloski, JM Tingey, WS Callaway III, GA Cooke, ME Johnson, MG Thien, DJ Washenfelder, JJ Davis, MN Hall, GL Smith, SL Thomson, and Y Onishi. 2007. Estimate of Hanford Waste Insoluble Solid Particle Size and Density Distribution. PNWD-3824, WTP-RPT-153, Rev. 0, Battelle-Pacific Northwest Division, Richland, WA.

Wells BE, KI Johnson, DR Rector, and DS Trent. 2008. S-102 Transfer Pump Restriction Modeling Results. PNNL-17424, Pacific Northwest National Laboratory, Richland, WA. 
Appendix A

\section{Gamma-Monitoring System Data}





\section{Appendix A: Gamma-Monitoring System Data}

The gamma-monitoring system data of Figure 2.3, Section 2.3.2.1, and additional data of interest are listed in Table A.1.

Table A.1. Gamma-Monitoring System Data

\begin{tabular}{|c|c|c|c|c|c|}
\hline $\begin{array}{c}\text { Figure } 2.3 \\
\text { Profile Number } \\
\text { [Identification \#] }\end{array}$ & Data File & Date & Time $^{(a)}$ & $\begin{array}{l}\text { Height in } \\
\text { Vessel (in.) }\end{array}$ & $\begin{array}{l}\text { Gross Rate } \\
\text { (cps) } \\
\text { [Counts/Live } \\
\text { Time] }\end{array}$ \\
\hline \multirow{14}{*}{$\mathrm{NA}^{(\mathrm{b})}$} & \multirow{14}{*}{$\begin{array}{c}15 \mathrm{~F}-\text { Above } \\
850 \mathrm{keV} \text { Depth } \\
\text { Profile_-04 } 27 \\
\text { 2000.xls }\end{array}$} & \multirow[t]{14}{*}{$4 / 27 / 00$} & \multirow[t]{14}{*}{$14: 46-15: 30$} & 290 & 36.467 \\
\hline & & & & 269 & 34.800 \\
\hline & & & & 248 & 34.511 \\
\hline & & & & 227 & 34.367 \\
\hline & & & & 206 & 35.511 \\
\hline & & & & 185 & 35.300 \\
\hline & & & & 164 & 33.822 \\
\hline & & & & 143 & 34.389 \\
\hline & & & & 122 & 33.733 \\
\hline & & & & 101 & 33.642 \\
\hline & & & & 80 & 33.289 \\
\hline & & & & 68 & 32.311 \\
\hline & & & & 56 & 34.822 \\
\hline & & & & 44 & 47.056 \\
\hline \multirow{15}{*}{ NA } & \multirow{15}{*}{$\begin{array}{c}\text { 15C-Above } \\
850 \mathrm{keV} \text { Depth } \\
\text { Profile-04 } 30 \\
\text { 2000(1).xls }\end{array}$} & \multirow[t]{22}{*}{$4 / 30 / 00$} & \multirow[t]{15}{*}{$3: 04-3: 51$} & 290 & 38.156 \\
\hline & & & & 269 & 35.344 \\
\hline & & & & 248 & 35.289 \\
\hline & & & & 227 & 34.222 \\
\hline & & & & 206 & 34.989 \\
\hline & & & & 185 & 34.556 \\
\hline & & & & 164 & 35.089 \\
\hline & & & & 143 & 35.389 \\
\hline & & & & 122 & 35.100 \\
\hline & & & & 101 & 35.489 \\
\hline & & & & 80 & 35.422 \\
\hline & & & & 59 & 29.979 \\
\hline & & & & 38 & 31.389 \\
\hline & & & & 17 & 230.023 \\
\hline & & & & 16 & 300.267 \\
\hline \multirow{7}{*}{ NA } & \multirow{7}{*}{$\begin{array}{c}15 \mathrm{C} \text {-Above } \\
850 \mathrm{keV} \text { Depth } \\
\text { Profile_-04 } 30 \\
2000(2) . \mathrm{xls}\end{array}$} & & \multirow[t]{7}{*}{$4: 57-5: 45$} & 290 & 35.367 \\
\hline & & & & 269 & 33.278 \\
\hline & & & & 248 & 34.678 \\
\hline & & & & 227 & 33.544 \\
\hline & & & & 206 & 35.089 \\
\hline & & & & 185 & 32.622 \\
\hline & & & & 164 & 35.811 \\
\hline
\end{tabular}

A.1 
Table A.1 (contd)

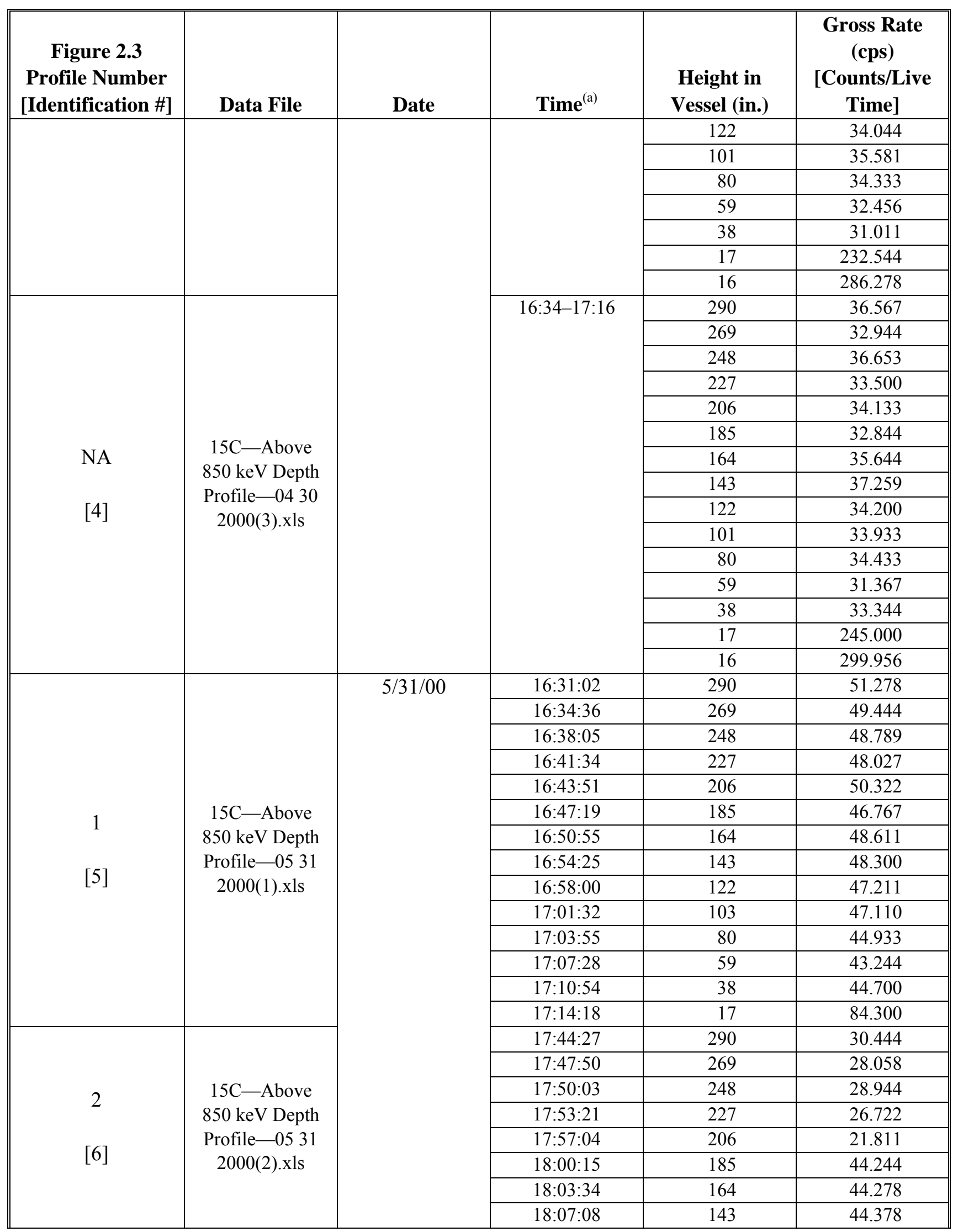


Table A.1 (contd)

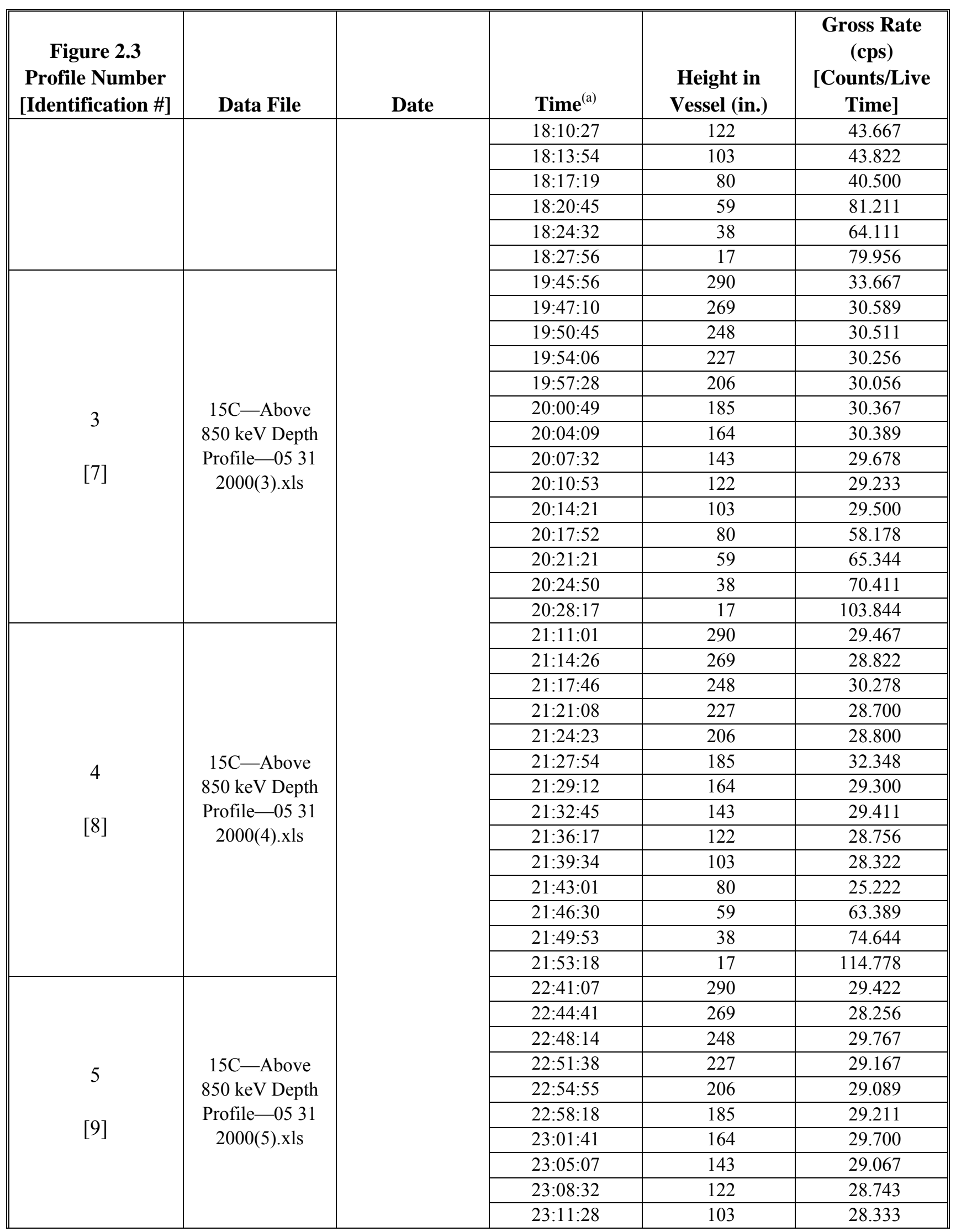


Table A.1 (contd)

\begin{tabular}{|c|c|c|c|c|c|}
\hline $\begin{array}{c}\text { Figure } 2.3 \\
\text { Profile Number } \\
\text { [Identification \#] }\end{array}$ & Data File & Date & Time $^{(\mathrm{a})}$ & $\begin{array}{l}\text { Height in } \\
\text { Vessel (in.) }\end{array}$ & $\begin{array}{c}\text { Gross Rate } \\
\text { (cps) } \\
\text { [Counts/Live } \\
\text { Time] }\end{array}$ \\
\hline & & & $23: 14: 58$ & 80 & 25.400 \\
\hline & & & $23: 18: 24$ & 59 & 59.111 \\
\hline & & & $23: 21: 51$ & 38 & 81.100 \\
\hline & & & $23: 25: 20$ & 17 & 125.144 \\
\hline \multirow{15}{*}{ NA } & \multirow{15}{*}{$\begin{array}{c}15 \mathrm{C} \text {-Above } \\
850 \mathrm{keV} \text { Depth } \\
\text { Profile-06 } 01 \\
2000(10) . \mathrm{xls}\end{array}$} & \multirow[t]{30}{*}{$6 / 1 / 00$} & $15: 13$ & 290 & 29.078 \\
\hline & & & $15: 16$ & 269 & 27.100 \\
\hline & & & $15: 20$ & 248 & 27.789 \\
\hline & & & $15: 23$ & 227 & 27.556 \\
\hline & & & $15: 27$ & 206 & 28.400 \\
\hline & & & $15: 30$ & 185 & 28.844 \\
\hline & & & $15: 34$ & 164 & 27.467 \\
\hline & & & $15: 38$ & 143 & 36.000 \\
\hline & & & $15: 41$ & 122 & 27.811 \\
\hline & & & $15: 45$ & 101 & 26.744 \\
\hline & & & $15: 48$ & 80 & 24.789 \\
\hline & & & $15: 52$ & 59 & 24.267 \\
\hline & & & $15: 55$ & 38 & 43.789 \\
\hline & & & 15:59 & 17 & 140.011 \\
\hline & & & $16: 02$ & 16 & 141.900 \\
\hline \multirow{15}{*}{ [11] } & \multirow{15}{*}{$\begin{array}{c}15 \mathrm{C} \text {-Above } \\
850 \mathrm{keV} \text { Depth } \\
\text { Profile-06 } 01 \\
2000(11) . \mathrm{xls}\end{array}$} & & $16: 40$ & 290 & 27.567 \\
\hline & & & $16: 43$ & 269 & 26.833 \\
\hline & & & $16: 47$ & 248 & 27.422 \\
\hline & & & $16: 50$ & 227 & 26.500 \\
\hline & & & $16: 54$ & 206 & 28.022 \\
\hline & & & $16: 57$ & 185 & 27.233 \\
\hline & & & $17: 01$ & 164 & 27.467 \\
\hline & & & $17: 05$ & 143 & 26.789 \\
\hline & & & $17: 08$ & 122 & 25.511 \\
\hline & & & $17: 12$ & 101 & 27.034 \\
\hline & & & $17: 15$ & 80 & 24.156 \\
\hline & & & $17: 19$ & 59 & 23.311 \\
\hline & & & $17: 22$ & 38 & 38.300 \\
\hline & & & $17: 26$ & 17 & 138.422 \\
\hline & & & $17: 29$ & 16 & 142.611 \\
\hline \multirow{10}{*}{ [12] } & \multirow{10}{*}{$\begin{array}{c}15 \mathrm{C}-\text {-Above } \\
850 \mathrm{keV} \text { Depth } \\
\text { Profile-06 } 02 \\
\text { 2000(9).xls }\end{array}$} & \multirow[t]{10}{*}{$6 / 2 / 00$} & $12: 27$ & 290 & 28.044 \\
\hline & & & $12: 30$ & 269 & 27.067 \\
\hline & & & $12: 34$ & 248 & 28.644 \\
\hline & & & $12: 37$ & 227 & 27.578 \\
\hline & & & $12: 41$ & 206 & 26.644 \\
\hline & & & $12: 44$ & 185 & 26.544 \\
\hline & & & $12: 48$ & 164 & 28.200 \\
\hline & & & $12: 52$ & 143 & 26.133 \\
\hline & & & $12: 55$ & 122 & 26.844 \\
\hline & & & $12: 59$ & 101 & 28.141 \\
\hline
\end{tabular}


Table A.1 (contd)

\begin{tabular}{|c|c|c|c|c|c|}
\hline $\begin{array}{c}\text { Figure } 2.3 \\
\text { Profile Number } \\
\text { [Identification \#] }\end{array}$ & Data File & Date & Time $^{(a)}$ & $\begin{array}{l}\text { Height in } \\
\text { Vessel (in.) }\end{array}$ & $\begin{array}{c}\text { Gross Rate } \\
\text { (cps) } \\
\text { [Counts/Live } \\
\text { Time] }\end{array}$ \\
\hline & & & $13: 02$ & 80 & 23.795 \\
\hline & & & 13:06 & 59 & 23.400 \\
\hline & & & 13:09 & 38 & 27.122 \\
\hline & & & $13: 13$ & 17 & 157.822 \\
\hline & & & $13: 16$ & 15 & 160.856 \\
\hline \multicolumn{6}{|c|}{$\begin{array}{l}\text { (a) 5/31/00 times from file } 15 \mathrm{C}-\mathrm{A}-000531(1)-80 \text { Spectra.xls. } 6 / 1 \text { and } 6 / 2 / 00 \text { times inferred from start times listed in } \\
\text { Appendix B Master Timeline.xls of Carlson et al. (2001) and time intervals of } 15 \mathrm{C}-\mathrm{A}-000531(1)-80 \text { Spectra.xls. } \\
\text { (b) Not applicable. }\end{array}$} \\
\hline
\end{tabular}

Carlson AB, PJ Certa, TM Hohl, JR Bellomy III, TW Crawford, DC Hedengren, AM Templeton, HS Fisher, SJ Greenwood, DG Douglas, and WJ Ulbright Jr. 2001. Test Report, 241-AZ-101 Mixer Pump Test. RPP-6548, Rev. 1, Numatec Hanford Corporation, Richland, WA. 

PNNL-18327

\section{Distribution}

No. of

Copies

OFFSITE
No. of

Copies

ONSITE

3 WRPS

M. Thien H6-03

D.H. Shuford H6-03

D.J. Washenfelder R2-58

$1 \underline{\text { ORP }}$

J-S Shuen H6-60

7 Pacific Northwest National Laboratory

J. M. Cuta

K7-15

J. A. Fort

$\mathrm{K} 7-15$

P. A. Gauglitz

K9-75

J. J. Ressler

K5-25

P. A. Scott

K7-15

B. E. Wells (2)

K7-15

Distr. 1 